\title{
An integrated approach towards the development of novel antifungal agents containing thiadiazole: synthesis and a combined similarity search, homology modelling, molecular dynamics and molecular docking study
}

Mustafa Er ${ }^{\text {* }}$, Abdulati Miftah Abounakhla ${ }^{1}$, Hakan Tahtaci', Ali Hasin Bawah', Süleyman Selim Çınaroğlu², Abdurrahman Onaran ${ }^{3}$ and Abdulilah Ece ${ }^{4^{*}}$ (])

\begin{abstract}
Background: This study aims to synthesise and characterise novel compounds containing 2-amino-1,3,4-thiadiazole and their acyl derivatives and to investigate antifungal activities. Similarity search, molecular dynamics and molecular docking were also studied to find out a potential target and enlighten the inhibition mechanism.

Results: As a first step, 2-amino-1,3,4-thiadiazole derivatives (compounds $\mathbf{3}$ and $\mathbf{4}$ ) were synthesised with high yields (81 and $84 \%$ ). The target compounds ( $\mathbf{6} \mathbf{a}-\mathbf{n}$ and $\mathbf{7 a} \mathbf{a}$ ) were then synthesised with moderate to high yields (56-87\%) by reacting $\mathbf{3}$ and $\mathbf{4}$ with various acyl chloride derivatives $(\mathbf{5} \mathbf{a}-\mathbf{n})$. The synthesized compounds were characterized using the IR, ${ }^{1} \mathrm{H}-\mathrm{NMR},{ }^{13} \mathrm{C}-\mathrm{NMR}$, Mass, X-ray (compound $\mathbf{7 n}$ ) and elemental analysis techniques. Later, the in vitro antifungal activities of the synthesised compounds were determined. The inhibition zones exhibited by the compounds against the tested fungi, their minimum fungicidal activities, minimum inhibitory concentration and the lethal dose values $\left(L_{50}\right)$ were determined. The compounds exhibited moderate to high levels of activity against all tested pathogens. Finally, in silico modelling was used to enlighten inhibition mechanism using ligand and structure-based methods. As an initial step, similarity search was carried out and the resulting proteins that belong to Homo sapiens were used as reference in sequence similarity search to find the corresponding amino acid sequences in target organisms. Homology modelling was used to construct the protein structure. The stabilised protein structure obtained from molecular dynamics simulation was used in molecular docking.
\end{abstract}

Conclusion: The overall results presented here might be a good starting point for the identification of novel and more active compounds as antifungal agents.

Keywords: 2-Amino-1,3,4-thiadiazole, Acylation, Antifungal, Homology modelling, Molecular dynamics, Molecular docking

\footnotetext{
*Correspondence: mustafaer@karabuk.edu.tr; aece@biruni.edu.tr

${ }^{1}$ Department of Chemistry, Faculty of Science, Karabuk University,

78050 Karabuk, Turkey

${ }^{4}$ Department of Pharmaceutical Chemistry, Faculty of Pharmacy, Biruni

University, 34010 Istanbul, Turkey

Full list of author information is available at the end of the article
}

(c) The Author(s) 2018. This article is distributed under the terms of the Creative Commons Attribution 4.0 International License (http://creativecommons.org/licenses/by/4.0/), which permits unrestricted use, distribution, and reproduction in any medium, provided you give appropriate credit to the original author(s) and the source, provide a link to the Creative Commons license, and indicate if changes were made. The Creative Commons Public Domain Dedication waiver (http://creativecommons.org/ publicdomain/zero/1.0/) applies to the data made available in this article, unless otherwise stated. 


\section{Background}

Due to widespread of infectious diseases killing millions of people, the need for new active, safer and more potential antimicrobial agents has increased dramatically. Accordingly, researchers focus on synthesising novel compounds and their derivatives having different physiochemical properties which promises high activities with no or fewer side effects. Heterocyclic compounds are widespread in nature and are used in many fields. It has been known for many years that heterocyclic compounds, especially those containing nitrogen and sulphur atoms, have a variety of biological activities [1-3].

Thiadiazole is a five-membered heterocyclic ring system which contains two nitrogen and one sulphur atom with the molecular formula of $\mathrm{C}_{2} \mathrm{H}_{2} \mathrm{~N}_{2} \mathrm{~S}$. 1,3,4-Thiadiazole and its derivatives have become the focus of attention in drug, agriculture and material chemistry due to their high activity in $2^{\prime}$ and $5^{\prime}$ positions in substitution reactions $[4,5]$.

The two-electron donor nitrogen system $(-\mathrm{N}=\mathrm{C}-\mathrm{S})$ and hydrogen-binding domain allow for great structural<smiles>[R]C(=O)Nc1nnc(Cc2c(Cl)cccc2Cl)s1</smiles>

R:

\section{Reaction conditions:}

i : Trifluoroacetic acid (TFA), $60{ }^{\circ} \mathrm{C}$, reflux, $3-5 \mathrm{~h}$ ii : Dry Benzene, dry pyridine, reflux, 4-6 h 
stability and is known to be the component responsible for biological activity [6, 7].

1,3,4-Thiadiazole and its derivatives have an important place among compounds with hetero rings containing nitrogen and sulphur atoms and have been extensively used in pharmaceutics due to their biological activity such as antifungal, antibacterial, antioxidant, anti-inflammatory, anticonvulsant, antituberculosis, and antiproliferative activities [8-20].

The drug design begins with the synthesis of a compound that exhibits a promising biological profile (lead compound), then the activity profile is optimised and finally ends with chemical synthesis of this final compound (drug candidate).
Computer Aided Drug Design helps to design novel and active compounds which also have fewer side effects. In that respect, in silico molecular modelling has been playing an increasingly important role in the development and synthesis of new drug substances and in understanding the basis of drug-target protein interactions [21-23].

In the light of the literature survey, the purpose of this study is to synthesise a number of compounds with different substituted groups containing 1,3,4-thiadiazoles ring and their acyl derivatives, to investigate their antifungal activities and finally to discuss the inhibition mechanism by means of computational tools.<smiles>[X]c1cccc(Cl)c1Cc1nnc(N)s1</smiles>

3 and 4

R:

a:<smiles>Cc1ccccc1</smiles>

b:<smiles>Cc1ccc([N+](=O)[O-])cc1</smiles>

c:<smiles>CSc1ccc(C)cc1</smiles>

d:

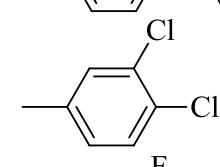

e:<smiles>Cc1ccc(F)c(F)c1</smiles>

f:<smiles>COc1ccc(C)cc1OC</smiles>

g<smiles>COc1cc(C)cc(OC)c1</smiles>

h:<smiles>Cc1cc(F)cc(F)c1</smiles>

i:<smiles>Cc1cc(Cl)cc(Cl)c1</smiles>

j:

k:<smiles>Cc1ccc(C(F)(F)F)cc1</smiles>

I:<smiles>Cc1ccc(C#N)cc1</smiles>

m: $\quad-\mathrm{CH}_{3}$

n: $\quad-\mathrm{OCH}_{2} \mathrm{CH}_{3}$<smiles>[X]c1cccc(Cl)c1Cc1nnc(NC([R])([Si])C2([O-])CC2)s1</smiles><smiles></smiles>

6a-n and 7a-n<smiles>Cl[C@H]1CC=C[C@H]1Cc1ccccn1</smiles> 


\section{Results and discussion}

\section{Chemistry}

In the first part of the study, the thiadiazole compounds (3 and 4) were synthesised from the reaction of the compounds 1 or $\mathbf{2}$ (purchased) with the thiosemicarbazide in trifluoroacetic acid (TFA) at $60{ }^{\circ} \mathrm{C}$. The compounds 3 and 4 were obtained as specified in the literature [24, 25].

The acyl derivatives of thiadiazole, which are the target compounds of the study, were obtained from the reactions of acyl derivatives $(\mathbf{5} \mathbf{a}-\mathbf{n})$ with the compounds $\mathbf{3}$ and 4. All the synthesised 28 compounds $(6 \mathbf{a}-\mathbf{n}$ and $7 \mathbf{a}-$ n) were obtained in moderate to good yields (56-87\%). The synthetic route employed to synthesise these compounds is given in Scheme 1 and the formation mechanism is shown in Scheme 2.

As can be seen from the reaction mechanism in Scheme 2, the main reaction proceeds through a typical nucleophilic acyl substitution reaction.

The structure of the compounds obtained were elucidated using the FT-IR, ${ }^{1} \mathrm{H}$ NMR, ${ }^{13} \mathrm{C}$ NMR, elemental

Table 1 Inhibition zones of compounds against plant pathogens

\begin{tabular}{|c|c|c|c|c|c|c|}
\hline \multirow[t]{4}{*}{ Compounds } & \multicolumn{6}{|c|}{ Mean zone of inhibition $(\mathrm{mm})^{a}$} \\
\hline & \multirow{2}{*}{\multicolumn{2}{|c|}{$\begin{array}{l}\text { Fusarium oxysporum f. sp. lycopersici } \\
\text { Doses }(\mu \mathrm{g} / \mathrm{ml})\end{array}$}} & \multirow{2}{*}{\multicolumn{2}{|c|}{$\begin{array}{l}\text { Monilia fructigena } \\
\text { Doses }(\mu \mathrm{g} / \mathrm{ml})\end{array}$}} & \multirow{2}{*}{\multicolumn{2}{|c|}{$\frac{\text { Alternaria solani }}{\text { Doses }(\mu \mathrm{g} / \mathrm{ml})}$}} \\
\hline & & & & & & \\
\hline & 500 & 1000 & 500 & 1000 & 500 & 1000 \\
\hline $\mathrm{C}-$ & \multicolumn{2}{|l|}{$0 \pm 0.00$} & \multicolumn{2}{|l|}{$0 \pm 0.00$} & \multicolumn{2}{|l|}{$0 \pm 0.00$} \\
\hline 3 & $10.12 \pm 0.91$ & $12.35 \pm 0.52$ & $14.16 \pm 0.80$ & $18.19 \pm 0.86$ & $12.45 \pm 0.49$ & $14.81 \pm 0.56$ \\
\hline 4 & $14.67 \pm 0.93$ & $17.81 \pm 1.02$ & $11.19 \pm 0.59$ & $14.25 \pm 0.54$ & $9.35 \pm 0.33$ & $13.18 \pm 1.25$ \\
\hline $6 a$ & $13.19 \pm 0.67$ & $17.08 \pm 0.72$ & $13.40 \pm 0.23$ & $15.88 \pm 0.41$ & $10.76 \pm 0.29$ & $13.31 \pm 0.84$ \\
\hline $6 b$ & $10.92 \pm 0.22$ & $15.68 \pm 0.97$ & $16.87 \pm 0.32$ & $20.08 \pm 0.40$ & $10.40 \pm 0.42$ & $14.61 \pm 0.37$ \\
\hline $6 c$ & $13.83 \pm 0.30$ & $17.82 \pm 0.09$ & $16.31 \pm 1.36$ & $18.34 \pm 0.34$ & $10.70 \pm 0.83$ & $14.73 \pm 0.94$ \\
\hline $6 d$ & $11.27 \pm 0.53$ & $15.33 \pm 0.36$ & $14.44 \pm 3.38$ & $18.09 \pm 1.67$ & $9.18 \pm 0.59$ & $11.73 \pm 0.34$ \\
\hline $6 e$ & $11.11 \pm 0.61$ & $15.14 \pm 1.02$ & $12.20 \pm 0.74$ & $17.17 \pm 1.20$ & $14.27 \pm 3.18$ & $17.15 \pm 1.68$ \\
\hline $6 f$ & $13.95 \pm 0.58$ & $17.30 \pm 0.73$ & $14.45 \pm 0.60$ & $18.65 \pm 0.51$ & $9.74 \pm 0.63$ & $15.21 \pm 1.15$ \\
\hline $6 \mathrm{~g}$ & $15.51 \pm 0.28$ & $18.53 \pm 0.39$ & $16.08 \pm 0.19$ & $18.30 \pm 0.16$ & $13.44 \pm 1.00$ & $16.92 \pm 0.12$ \\
\hline $6 h$ & $15.25 \pm 0.30$ & $19.14 \pm 0.40$ & $11.59 \pm 0.58$ & $15.13 \pm 1.68$ & $9.57 \pm 0.30$ & $11.94 \pm 0.35$ \\
\hline $6 i$ & $10.33 \pm 1.29$ & $13.88 \pm 1.08$ & $12.37 \pm 3.66$ & $17.40 \pm 1.21$ & $9.96 \pm 0.33$ & $12.56 \pm 0.34$ \\
\hline $6 \mathbf{j}$ & $13.31 \pm 0.87$ & $18.80 \pm 0.74$ & $15.28 \pm 0.85$ & $17.93 \pm 0.50$ & $11.37 \pm 1.38$ & $15.27 \pm 1.29$ \\
\hline $6 k$ & $12.47 \pm 0.78$ & $16.67 \pm 0.94$ & $19.95 \pm 1.49$ & $20.52 \pm 1.24$ & $11.16 \pm 0.20$ & $15.19 \pm 0.90$ \\
\hline 61 & $13.25 \pm 1.59$ & $17.52 \pm 0.45$ & $11.44 \pm 0.31$ & $15.84 \pm 0.39$ & $7.31 \pm 0.03$ & $10.73 \pm 0.08$ \\
\hline $6 \mathrm{~m}$ & $13.69 \pm 1.28$ & $18.69 \pm 1.28$ & $11.37 \pm 1.22$ & $16.59 \pm 1.15$ & $11.10 \pm 0.36$ & $14.61 \pm 0.56$ \\
\hline $6 n$ & $14.36 \pm 0.44$ & $17.76 \pm 0.16$ & $12.71 \pm 0.52$ & $18.23 \pm 0.58$ & $12.05 \pm 0.29$ & $15.96 \pm 0.16$ \\
\hline $7 a$ & $13.48 \pm 1.07$ & $18.51 \pm 1.71$ & $14.31 \pm 0.33$ & $17.99 \pm 0.29$ & $11.29 \pm 0.25$ & $14.01 \pm 1.11$ \\
\hline $7 b$ & $13.40 \pm 1.39$ & $17.98 \pm 0.58$ & $16.83 \pm 1.89$ & $20.04 \pm 0.95$ & $10.67 \pm 0.48$ & $13.73 \pm 0.89$ \\
\hline $7 c$ & $15.71 \pm 1.25$ & $19.51 \pm 0.78$ & $15.34 \pm 0.27$ & $17.64 \pm 0.38$ & $10.18 \pm 0.59$ & $14.10 \pm 1.64$ \\
\hline $7 d$ & $11.39 \pm 0.04$ & $14.80 \pm 0.45$ & $14.95 \pm 0.32$ & $17.72 \pm 0.23$ & $10.69 \pm 0.64$ & $12.57 \pm 0.63$ \\
\hline $7 e$ & $13.48 \pm 0.30$ & $17.33 \pm 0.52$ & $10.73 \pm 0.51$ & $16.83 \pm 0.36$ & $10.90 \pm 0.32$ & $16.24 \pm 0.26$ \\
\hline $7 f$ & $13.31 \pm 0.31$ & $16.56 \pm 0.61$ & $12.42 \pm 1.43$ & $16.54 \pm 0.79$ & $8.02 \pm 0.60$ & $10.88 \pm 0.37$ \\
\hline $7 g$ & $12.22 \pm 0.29$ & $15.91 \pm 0.63$ & $11.90 \pm 0.71$ & $21.23 \pm 0.97$ & $12.19 \pm 0.52$ & $15.88 \pm 1.13$ \\
\hline $7 \mathrm{~h}$ & $14.68 \pm 0.94$ & $18.13 \pm 0.46$ & $11.65 \pm 0.89$ & $17.34 \pm 0.78$ & $7.72 \pm 0.44$ & $10.87 \pm 0.44$ \\
\hline $7 i$ & $12.57 \pm 0.41$ & $15.81 \pm 0.51$ & $14.84 \pm 0.23$ & $17.67 \pm 0.11$ & $9.04 \pm 0.46$ & $11.01 \pm 0.55$ \\
\hline $7 \mathbf{j}$ & $11.19 \pm 0.95$ & $16.40 \pm 0.55$ & $11.77 \pm 0.86$ & $20.16 \pm 1.81$ & $9.94 \pm 0.26$ & $15.38 \pm 0.05$ \\
\hline $7 k$ & $11.97 \pm 1.30$ & $15.90 \pm 1.00$ & $12.61 \pm 2.09$ & $16.66 \pm 0.94$ & $8.92 \pm 1.22$ & $11.38 \pm 0.49$ \\
\hline 71 & $13.55 \pm 0.37$ & $16.38 \pm 0.31$ & $9.36 \pm 0.92$ & $17.36 \pm 0.24$ & $9.90 \pm 0.21$ & $12.71 \pm 0.79$ \\
\hline $7 m$ & $13.59 \pm 1.88$ & $16.82 \pm 0.14$ & $10.17 \pm 1.15$ & $16.06 \pm 1.46$ & $6.86 \pm 0.63$ & $11.54 \pm 0.41$ \\
\hline $7 n$ & $13.65 \pm 0.69$ & $17.54 \pm 0.52$ & $17.31 \pm 1.02$ & $18.74 \pm 0.31$ & $12.50 \pm 0.45$ & $18.19 \pm 0.84$ \\
\hline$C_{+}$ & $25.00 \pm 1.32$ & & $25.00 \pm 0.98$ & & $25.00 \pm 0.53$ & \\
\hline
\end{tabular}

Inhibition zone (IZ) \pm standard deviation (SD); C+, positive control (Thiram); C-, negative control (DMSO)

a Mean of three assays 
Table 2 Percentage inhibition of compounds against test fungi (\%)

\begin{tabular}{|c|c|c|c|c|c|c|}
\hline \multirow[t]{3}{*}{ Compounds } & \multirow{2}{*}{\multicolumn{2}{|c|}{$\frac{\text { FOL }}{\text { Doses }(\mu \mathrm{g} / \mathrm{ml})}$}} & \multirow{2}{*}{\multicolumn{2}{|c|}{$\frac{\text { MF }}{\text { Doses }(\mu \mathrm{g} / \mathrm{ml})}$}} & \multirow{2}{*}{\multicolumn{2}{|c|}{$\frac{\text { AS }}{\text { Doses }(\mu \mathrm{g} / \mathrm{ml})}$}} \\
\hline & & & & & & \\
\hline & 500 & 1000 & 500 & 500 & 1000 & 500 \\
\hline $\mathrm{C}-$ & - & - & - & - & - & - \\
\hline 3 & 40 & 49 & 57 & 73 & 50 & 59 \\
\hline 4 & 59 & 71 & 45 & 57 & 37 & 53 \\
\hline $6 a$ & 53 & 68 & 54 & 64 & 43 & 53 \\
\hline $6 b$ & 44 & 63 & 67 & 80 & 42 & 58 \\
\hline $6 c$ & 55 & 71 & 65 & 73 & 43 & 59 \\
\hline $6 d$ & 45 & 61 & 58 & 72 & 37 & 47 \\
\hline $6 e$ & 44 & 61 & 49 & 69 & 57 & 69 \\
\hline $6 f$ & 56 & 69 & 58 & 75 & 39 & 61 \\
\hline $6 g$ & 62 & 74 & 64 & 73 & 54 & 68 \\
\hline $6 \mathrm{~h}$ & 61 & 77 & 46 & 61 & 38 & 48 \\
\hline $6 i$ & 41 & 56 & 49 & 70 & 40 & 50 \\
\hline $6 j$ & 53 & 75 & 61 & 72 & 45 & 61 \\
\hline $6 k$ & 50 & 67 & 80 & 82 & 45 & 61 \\
\hline 61 & 53 & 70 & 46 & 63 & 29 & 43 \\
\hline $6 \mathrm{~m}$ & 55 & 75 & 45 & 66 & 44 & 58 \\
\hline $6 n$ & 57 & 71 & 51 & 73 & 48 & 64 \\
\hline $7 a$ & 54 & 74 & 57 & 72 & 45 & 56 \\
\hline $7 b$ & 54 & 72 & 67 & 80 & 43 & 55 \\
\hline $7 c$ & 63 & 78 & 61 & 71 & 41 & 56 \\
\hline $7 d$ & 46 & 59 & 60 & 71 & 43 & 50 \\
\hline $7 e$ & 54 & 69 & 43 & 67 & 44 & 65 \\
\hline $7 f$ & 53 & 66 & 50 & 66 & 32 & 44 \\
\hline $7 g$ & 49 & 64 & 48 & 85 & 49 & 64 \\
\hline 7h & 59 & 73 & 47 & 69 & 31 & 43 \\
\hline $7 i$ & 50 & 63 & 59 & 71 & 36 & 44 \\
\hline $7 \mathbf{j}$ & 45 & 66 & 47 & 81 & 40 & 62 \\
\hline $7 k$ & 48 & 64 & 50 & 67 & 36 & 46 \\
\hline 7I & 54 & 66 & 37 & 69 & 40 & 51 \\
\hline $7 m$ & 54 & 67 & 41 & 64 & 27 & 46 \\
\hline $7 n$ & 55 & 70 & 69 & 75 & 50 & 73 \\
\hline $\mathrm{C}+$ & 100 & 100 & 100 & 100 & 100 & 100 \\
\hline
\end{tabular}

(-), no percentage inhibition; FOL, Fusarium oxysporum $f$. sp. lycopersici; MF, Monilia fructigena; AS, Alternaria solani

analysis and mass spectroscopy techniques. The results are given in detail in "Experimental" section, and the relevant spectra are given in Additional file 1. In addition, the structure of the compound $\mathbf{7 n}$, obtained as a single crystal, was explained with X-ray spectroscopy.

The crystal structure of the compound $\mathbf{7 n}$ and all X-ray data are provided in Additional file 1.

The target compounds in our study $(\mathbf{6 a}-\mathbf{n}$ and $7 \mathbf{a}-\mathbf{n})$ were synthesised in moderate to high yields (56-87\%) from the reaction of the acyl chloride derivatives $(5 \mathbf{a}-\mathbf{n})$ with the 2-amino-1,3,4-thiadiazole derivatives ( 3 and 4 ) in the presence of dry benzene.
In the IR spectra of the compounds $6 \mathbf{a}-\mathbf{n}$ and $7 \mathbf{a}-\mathbf{n}$, the symmetric and asymmetric absorption bands corresponding to $-\mathrm{NH}_{2}$ group (3261-3098 $\mathrm{cm}^{-1}$ ) disappear and instead, the $-\mathrm{NH}$ absorption bands at $3186-3092 \mathrm{~cm}^{-1}$ are observed which are the most significant evidences that the compounds were acylated.

Another significant evidence is the $\mathrm{C}=\mathrm{O}$ absorption band peaks seen at $1720-1624 \mathrm{~cm}^{-1}$. The appearance of the $-\mathrm{NH}$ and $\mathrm{C}=\mathrm{O}$ absorption bands in the IR spectra is another indication that the compounds $(6 \mathbf{a}-\mathbf{n}$ and $7 \mathbf{a}-\mathbf{n})$ were acylated. Other spectrum data of the compounds are presented in detail in "Experimental" section. 
Table 3 Antifungal activity values (LD ${ }_{50}, \mathrm{MFC}$ and MIC) of compounds against test fungi

\begin{tabular}{|c|c|c|c|}
\hline \multirow[t]{2}{*}{ Compounds } & \multicolumn{3}{|c|}{$\left(\mathrm{LD}_{50} / \mathrm{MFC} / \mathrm{MIC} \mu \mathrm{g} / \mathrm{ml}\right)$} \\
\hline & FOL & MF & AS \\
\hline 3 & $797 />1000 />125$ & $483 />500 /<31.25$ & $612 />1000 / 62.5$ \\
\hline 4 & $412 />500 / 62.5$ & $638 />1000 />250$ & $771 />1000 / 62.5$ \\
\hline $6 a$ & $534 />1000 / 125$ & $564 />1000 / 250$ & $737 />1000 / 125$ \\
\hline $6 b$ & $568 />1000 />250$ & $366 />250 /<31.25$ & $634 />1000 / 62.5$ \\
\hline $6 c$ & $505 />500 / 62.5$ & $457 />500 / 31.25$ & $658 />1000 / 62.5$ \\
\hline $6 d$ & $642 />1000 / 250$ & $476 />500 /<31.25$ & $961 />1000 />250$ \\
\hline $6 e$ & $603 />1000 / 250$ & $473 />500 /<31.25$ & $414 />500 /<31.25$ \\
\hline $6 f$ & $508 />500 / 250$ & $468 />500 /<31.25$ & $673 />1000 / 125$ \\
\hline $6 \mathrm{~g}$ & $474 />500 / 125$ & $470 />500 /<31.25$ & $546 />500 / 125$ \\
\hline $6 \mathrm{~h}$ & $490 />500 / 125$ & $679 />1000 / 250$ & $929 />1000 />250$ \\
\hline $6 i$ & $750 />1000 /<500$ & $563 />1000 / 125$ & $830 />1000 />250$ \\
\hline $6 j$ & $520 />500 / 62.5$ & $502 / 1000 / 125$ & $656 />1000 / 125$ \\
\hline $6 \mathrm{k}$ & $499 />500 / 62.5$ & $312 />250 /<31.25$ & $597 />1000 / 125$ \\
\hline 61 & $441 />500 / 125$ & $539 />1000 /<125$ & $1392 />1000 /<500$ \\
\hline $6 \mathrm{~m}$ & $406 />500 />31.25$ & $512 />500 / 62.5$ & $614 />1000 / 125$ \\
\hline $6 n$ & $404 />500 />31.25$ & $421 />500 / 31.25$ & $509 / 1000 / 62.5$ \\
\hline $7 a$ & $406 />500 / 62.5$ & $412 />500 / 31.25$ & $638 />1000 / 62.5$ \\
\hline $7 b$ & $432 />500 / 31.25$ & $320 />250 /<31.25$ & $691 />1000 />31.25$ \\
\hline $7 c$ & $350 />250 /<31.25$ & $395 /<500 /<31.25$ & $679 />1000 />31.25$ \\
\hline $7 d$ & $597 />1000 / 125$ & $394 />500 /<31.25$ & $788 />1000 /<62.5$ \\
\hline $7 e$ & $434 />500 / 250$ & $519 />500 / 125$ & $546 />500 />31.25$ \\
\hline $7 f$ & $453 />500 / 31.25$ & $485 />500 / 125$ & $1308 />1000 /<500$ \\
\hline $7 \mathrm{~g}$ & $509 />500 / 250$ & $371 />500 /<31.25$ & $519 />500 / 31.25$ \\
\hline $7 \mathrm{~h}$ & $398 />250 /<31.25$ & $480 />500 / 125$ & $1361 />1000 /<500$ \\
\hline $7 i$ & $522 />500 />31.25$ & $406 />500 / 31.25$ & $1107 />1000 / 250$ \\
\hline $7 j$ & $564 />1000 / 125$ & $405 />500 / 31.25$ & $637 />1000 / 62.5$ \\
\hline $7 \mathrm{k}$ & $519 />500 / 125$ & $488 />500 />125$ & $1091 />1000 / 250$ \\
\hline 기 & $453 />500 / 62.5$ & $546 />1000 / 62.5$ & $809 />1000 / 125$ \\
\hline $7 m$ & $443 />500 />31.25$ & $572 />1000 / 62.5$ & $1313 />1000 / 250$ \\
\hline $7 n$ & $418 />500 />31.25$ & $343 />500 /<31.25$ & $486 />500 / 61.25$ \\
\hline $\mathrm{C}+$ & $596 /<3000 />31.25$ & $717<3000 /<62.5$ & $565<3000 /<31.25$ \\
\hline
\end{tabular}

$\mathrm{LD}_{50}$, the amount of a substance, which causes the death of $50 \%$ (one half) of test fungi; MFC, minimum fungicidal concentration; MIC, minimum inhibitory concentration; $\mathrm{C}+$, positive control (Thiram $80 \%$ )

Also, when the ${ }^{1} \mathrm{H}$ NMR spectrums of these compounds are examined, the disappearance of the $-\mathrm{NH}_{2}$ proton signals observed at 7.69 and $7.08 \mathrm{ppm}$ for the compounds 3 and 4 and appearance of $-\mathrm{NH}$ signals as a singlet which shift at $13.40-12.09 \mathrm{ppm}$ due to the electron withdrawing property of the carbonyl group, are the most significant evidence that these compounds $(\mathbf{6} \mathbf{a}-\mathbf{n}$ and $7 \mathbf{a}-\mathbf{n})$ were acylated. This data is consistent with findings in the literature $[24,25]$. Other ${ }^{1} \mathrm{H}$ NMR spectrum data for the compounds are presented in "Experimental" section, and the relevant spectra are given in Additional file 1 .
Similarly, when we examine the ${ }^{13} \mathrm{C}$ NMR spectra of the target compounds $(\mathbf{6 a}-\mathbf{n}$ and $7 \mathbf{a}-\mathbf{n})$, the appearance of the $\mathrm{C}=\mathrm{O}$ carbonyl group peaks at 169.03$162.49 \mathrm{ppm}$ also supports that the amino group in the thiadiazole ring was acylated. The $\mathrm{C}-2$ carbon signals corresponding to the thiadiazole ring in the compounds $\mathbf{6 a}-\mathbf{n}$ and $7 \mathbf{a}-\mathbf{n}$ were observed in the range 161.12$150.26 \mathrm{ppm}$, and the peaks corresponding to the C-5 carbon were observed between 169.01 and $161.78 \mathrm{ppm}$. Other ${ }^{13} \mathrm{C}$ NMR spectrum data of the compounds are presented in detail in "Experimental" section.

In addition, the mass spectra of all the synthesised compounds were obtained and the products were also confirmed with the molecular ion peaks.

\section{In vitro antimicrobial activity studies}

The activity values of the compounds against the tested fungus species (inhibition zones and percentage inhibition values) are presented in Tables 1 and 2 . At the used doses of the compounds (500 and $1000 \mu \mathrm{g} / \mathrm{ml}$ ), varying levels of activity were observed for each fungus species. For all compounds and doses used, the most sensitive fungus species was found to be the Monillia fructigena pathogen. This is followed by Fusarium oxysporum $f$. sp. lycopersici (FOL) and Alternaria solani pathogens. For thiram, which was used for positive control purposes, a $25 \mathrm{~mm}$ inhibition zone was observed for all pathogens, and it inhibited their development at $100 \%$. DMSO, which was used in negative control, did not affect the development of pathogens. According to the results obtained, the smallest inhibition zones at $1000 \mu \mathrm{g} / \mathrm{ml}$ for FOL was found in compound $3(12.35 \mathrm{~mm})$, and the greatest was in compound $7 \mathbf{c}(19.51 \mathrm{~mm})$. In case of $M$. fructigena, the smallest inhibition zones was found in compound $4(14.25 \mathrm{~mm})$, and the greatest was in compound $7 \mathrm{~g}(21.23 \mathrm{~mm})$; the smallest for $A$. solani was in compound $6 \mathbf{l}(10.73 \mathrm{~mm})$, and the greatest in compound $7 \mathbf{n}$ with $18.19 \mathrm{~mm}$. In addition, the percent inhibition values that the compounds exhibit against the pathogens were between 49 and $77 \%$ at the $1000 \mu \mathrm{g} / \mathrm{ml}$ dose for FOL, between 61 and $85 \%$ for M. fructigena, and between 43 and $73 \%$ for A. solani (Table 2). It is clear that by increasing the doses used, $100 \%$ inhibition rates would be observed. The $\mathrm{LD}_{50}$, minimum fungicidal activity (MFC) and minimum inhibitory concentration (MIC) values of the compounds against the fungi were calculated (Table 3). Accordingly, the $\mathrm{LD}_{50}$ values were calculated to be between 350 and $797 \mu \mathrm{g} / \mathrm{ml}$ for FOL; between 312 and $679 \mu \mathrm{g} / \mathrm{ml}$ for $M$. fructigena, and between 414 and $1392 \mu \mathrm{g} / \mathrm{ml}$ for A. solani. Despite the overall variation according to the fungus type, the MFC values varied between $>250$ and $>1000 \mu \mathrm{g} / \mathrm{ml}$, and the MIC values varied between $<31.25$ and 500 . According to the results, it 
was found that the compounds exhibited high to moderate levels of activity against the tested organisms.

\section{Computational studies Identification of target protein}

Molecular docking is a value added tool in computer aided drug design. It helps us to understand inhibition mechanism of a drug or drug candidate against its target. Ligand similarity search is one of the techniques used for target prediction. This method compares structures of the studied compounds to the compounds with known targets in the databases. For the cases where experimental crystal structures are not available, homology modelling is used to build protein structure based on a template. Optimization or refinement of protein structures are done through molecular dynamics (MD) simulations.

Here we followed a multi-stage computational strategy in order to find a potential target. Initially, the most active two structures based on their $\mathrm{LD}_{50}$ values for each fungus (Alternaria solani; 6e, $7 \mathbf{n}$. Monilia fructigena; $\mathbf{6 k}$, 7b. Fusarium oxysporum $f$. sp. lycopersici; $7 \mathbf{c}, 7 \mathbf{7 h}$ ) were selected and used for the similarity search. A number of similar compounds corresponding to our structures was retrieved from NCBI's PubChem database. The resulting structures and their targets are listed in Table 4.

Proteins belonging to the most active compounds in Table 4 were selected for the BLAST search (SRC and ABL1). These proteins are members of non-receptor protein tyrosine kinases family. Besides, FAK1 in Table 4 is also a member of this protein family. On the other hand, some of protein kinases have been shown to be antifungal targets [26, 27]. As seen in Fig. 1, a highly conserved kinase domain is present in those three proteins. This region contains a ligand binding site targeted to design anticancer drugs in human, and many protein structures of this domain are available in the Protein Data Bank (PDB) [28-30]. Thus, these proteins (SRC, ABL1 and FAK1) were selected for further modelling of the target of our compounds.

As a first step, the amino acid sequences of SRC, ABL1 and FAK1 were retrieved from the Universal Protein Resource (UniProt) and then submitted to the BLAST search to find similar protein sequences present in our target organisms [31-33]. Although the BLAST is available for only two species, Fusarium oxysporum $f$. sp. lycopersici (FOL) and Alternaria solani (AS), the size of proteome information for AS is not adequate. Thus, the

Table 4 Similar structures obtained by similarity search through PubChem database (Tanimoto threshold $\geq 90 \%$ )

\begin{tabular}{|c|c|c|c|c|}
\hline Structure (PubChem CID) & Target gene (Uniprot ID) & Organism & Activity $(\mu \mathrm{M})$ & BioAssay AID \\
\hline 1103113 & SRC (P12931) & Homo sapiens & 1.3 & 485313 \\
\hline 2873325 & NS3 Helicase (P29846) & Hepatitis C Virus & Active & 720488 \\
\hline 1405531 & Grm8 (P70579) & Rattus norvegicus & Active & 488969 \\
\hline 2363161 & SRC (P12931) & Homo sapiens & 0.9 & 317425 \\
\hline 2363161 & ABL1 (P00519) & Homo sapiens & 0.406 & 317426 \\
\hline 2192320 & SRC (P12931) & Homo sapiens & 0.718 & 317425 \\
\hline 2192320 & ABL1 (P00519) & Homo sapiens & 0.272 & 317426 \\
\hline 4380426 & NPC1 (O15118) & Homo sapiens & 3.1623 & 485313 \\
\hline 4380426 & RAB9A (P51151) & Homo sapiens & 3.9811 & 485297 \\
\hline 4380426 & Smarca4 (Q3TKT4) & Mus musculus & Active & 602393 \\
\hline 4380426 & MDM4 (O15151) & Homo sapiens & Active & 485346 \\
\hline 4380426 & MDM2 (Q00987) & Homo sapiens & Active & 485346 \\
\hline 3787336 & PTBP1 (P26599) & Homo sapiens & Active & 2417 \\
\hline 3787336 & Cysteine protease (A6XG55) & Trypanosoma cruzi & 25.1189 & 1476 \\
\hline 878365 & SENP6 (Q9GZR1) & Homo sapiens & Active & 2599 \\
\hline 878365 & SENP7 (Q9BQF6) & Homo sapiens & 16.8 & 488904 \\
\hline 878365 & CASP3 (P42574) & Homo sapiens & 18.9 & 488901 \\
\hline 3669135 & Rorc (P51450) & Mus musculus & 17.7828 & 2551 \\
\hline 3669135 & SENP7 (Q9BQF6) & Homo sapiens & Active & 434973 \\
\hline 3669135 & PAFAH1B2 (P68402) & Homo sapiens & Active & 492953 \\
\hline 3669135 & MC4R (P32245) & Homo sapiens & Active & 540308 \\
\hline 753766 & FAK1 (Q05397) & Homo sapiens & 11.87 & 657571 \\
\hline 4420955 & FAK1 (Q05397) & Homo sapiens & 12.68 & 657571 \\
\hline
\end{tabular}




\begin{tabular}{|c|}
\hline 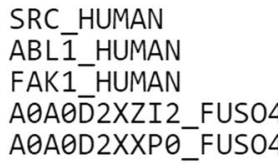 \\
\hline $\begin{array}{l}\text { SRC_HUMAN } \\
\text { ABL1_HUMAN } \\
\text { FAK1_HUMAN } \\
\text { AOAOD } 2 \text { XZI2_FUSO } 2 \text { _ } \\
\text { AOAOD2XXPO_FUSO }\end{array}$ \\
\hline 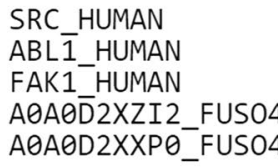 \\
\hline $\begin{array}{l}\text { SRC_HUMAN } \\
\text { ABL1_HUMAN } \\
\text { FAK1_HUMAN } \\
\text { AOAOD2XZI2_FUSO } 2 \text { 2 } \\
\text { AOAOD2XXPO_FUSO }\end{array}$ \\
\hline $\begin{array}{l}\text { SRC_HUMAN } \\
\text { ABL1_HUMAN } \\
\text { FAK1_HUMAN } \\
\text { AOAOD } 2 X Z I 2 \\
\text { AOAOD2XXPO }\end{array}$ \\
\hline
\end{tabular}

LRLEVKLGQGCFGEVWMGTWNGT - - - - TRVAIKTLKPGT - - - - - - - - MSPEAFLOE

ITMKHKLGGGQYGEVYEGVWKKY - - SLTVAVKTLKEDT-- - - - - - MEVEEFLKE

IELGRCIGEGQFGDVHQGIYMSPENPALAVAIKTCKNCTS - . . . . - - DSVREKFLQE WMKGALIGQGSFGSVYLALHAVT - - -GELLAVKQVETPAP GANSQGDTRKKGMIEALKRE YSKEYCIGGGSFGKVYKGVDKRT - - GQAVAIKVIDIESA---.--EDEVEDIIQE

AQVMKKLRHEKLVQLYAVVS-EEPIYIVTEYMSKGSLLDFLKGETGKYLRLPQLVDMAAQ AAVMKEIKHPNLVQLLGVCTREPPFYIITEFMTYGNLLDYLRECNRQEVNAVVLLYMATQ ALTMRQFDHPHIVKLIGVIT-ENPVWIIMELCTLGELRSFLQVR-KYSLDLASLILYAYQ ISLLRDLRHPNIVQYLGCSSSADYLNIFLEYVPGGSVQTILNSYGA-- LPEPLVRSFVRQ IAILSELQSPYVTKYYGSYAKGAE LWIVMEFCSGGSCADLMK - PGL - - IGEDYIAIIVRE

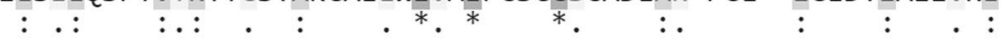

IASGMAYVERMNYVHRDLRAANILVGENLVCKVADFGLARLIEDNEYTA- - - - - - RQGA ISSAMEYLEKKNFIHRDLAARNCLVGENHLVKVADFGLSRLMTGDTYTA- - - - - - HAGA LSTALAYLESKRFVHRDIAARNVLVSSNDCVKLGDFGLSRYMEDSTYYK_-... - - ASKG ILTGLSYLHNRDI IHRDIKGANILVDNKGTIKISDFGISKKLEASNILNGANNNKHRPSL LLMGLDYLHTDKKLHRDVKAANVLLSSNGQVKLADFGVSGQLSATM- - - - - - TKKNTF : .:*:. : $* * *:$ : **:..: * ****:: :

KFPIKWTAPEAALYGRFTIKSDVWSFGILLTELTTKGRVPYPGMVNREVLDQVERGYRMP KFPIKWTAPESLAYNKFSIKSDVWAFGVLLWEIATYGMSPYPGIDLSQVYELLEKDYRME KLPIKWMAPESINFRRFTSASDVWMFGVCMWEILMHGVKPFQGVKNNDVIGRIENGERLP QGSVFWMAPEVVKQTSYTRKADIWSLGCLVVEM-MTGSHPFPDCSQLQAIFKIGGGKAAP VGTPFWMAPEVIKQSGYDHKADIWSLGITALEL-ANGEPPYADIHPMKVLFLIPKN - PPP

C-PPECPESLHDLMCQCWRKEPEERPTFEYLQAFLEDYF R-PEGCPEKVYELMRACWQWNPSDRPSFAEIHQAF - - - M-PPNCPPTLYSLMTKCWAYDPSRRPRFTELKAQLSTIL TIPEHASEAAKEFLAQTFEIDHNLRPSADQLIL - -SPFL RLEGNFTKAFKDFIELCLQRDPKDRPTAKDMLR - - HPFI .: : $\quad$ : **

Fig. 1 Multiple sequence alignment results of protein kinase domain of SRC, ABL1, FAK1, and FOL's proteins

Table 5 Alignment results from the BLAST search

\begin{tabular}{|c|c|c|c|c|c|c|c|}
\hline Query (UniProt ID) & Subject (UniProt ID) & \%ldentity & $\begin{array}{l}\text { Alignment } \\
\text { length }\end{array}$ & Mismatches & Gaps & E-value & Score \\
\hline SRC (P12931) & STE/STE11 (A0A0D2XZI2) & 28.030 & 264 & 161 & 8 & $3.14 \mathrm{e}-23$ & 104 \\
\hline ABL1 (P00519) & STE/STE20/YSK (A0A0D2XXP0) & 28.571 & 245 & 166 & 6 & $3.52 \mathrm{e}-26$ & 115 \\
\hline FAK1 (Q05397) & STE/STE20/YSK (A0A0D2XXP0) & 28.571 & 336 & 193 & 11 & $1.81 \mathrm{e}-28$ & 123 \\
\hline
\end{tabular}

BLAST search was performed for only FOL to identify similar protein sequences (Table 5).

Finally, two different proteins were identified (Table 5). A remarkable alignment with 33 identical and 61 similar positions was obtained at the protein kinase domain (Fig. 1). After the comparison of those two FOL's proteins with human proteins, A0A0D2XXP0 was found to be more similar to human proteins than A0A0D2XZI2. Besides, additional insertion sites were observed in the A0A0D2XZI2 which can cause a different conformational change at the tertiary structure, and also affect the ligand binding site (Fig. 1). Hence, A0A0D2XXP0 was 


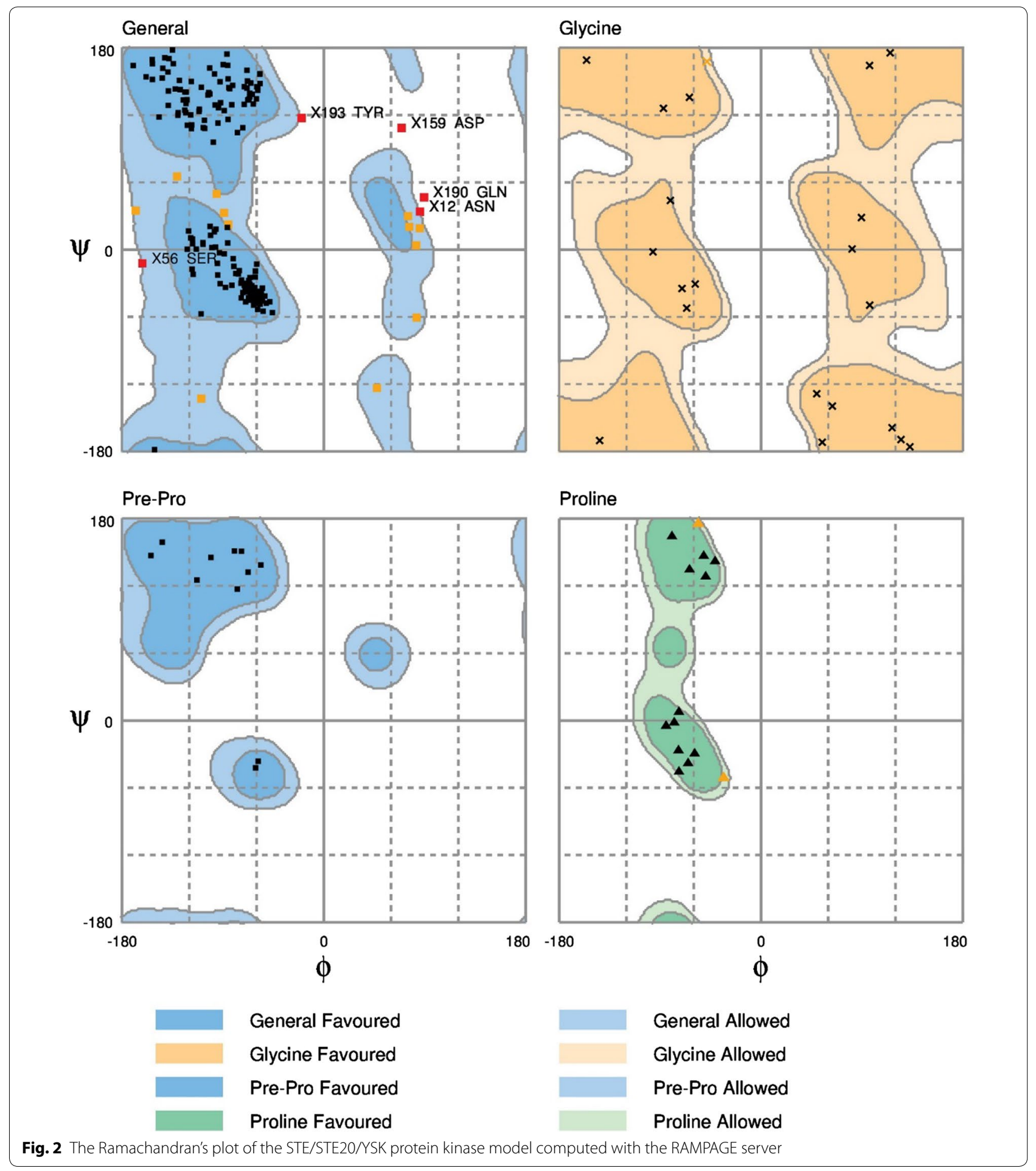




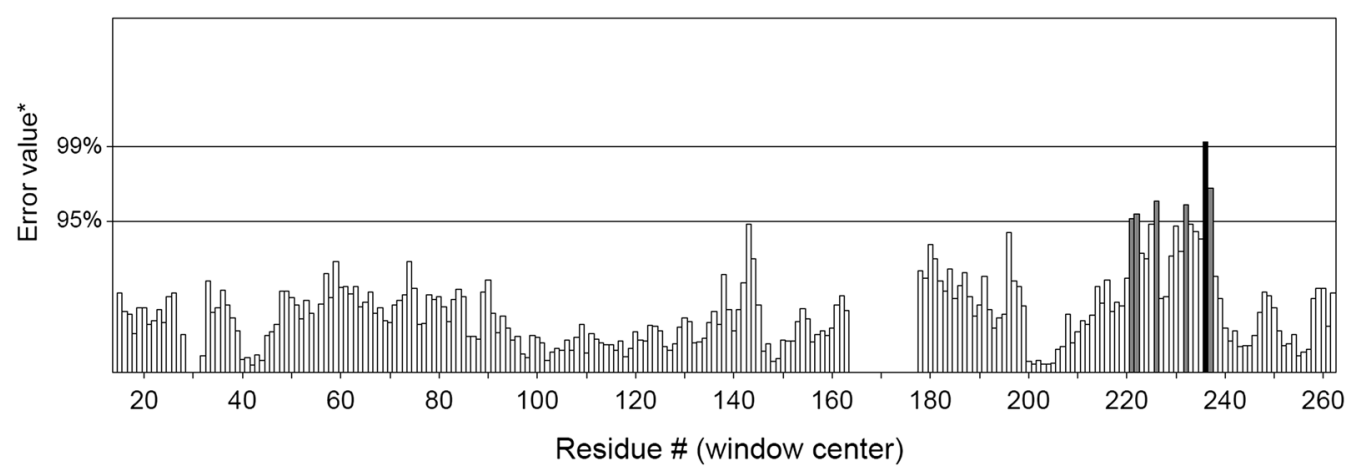

Fig. 3 ERRAT plot for measurement of the structural errors

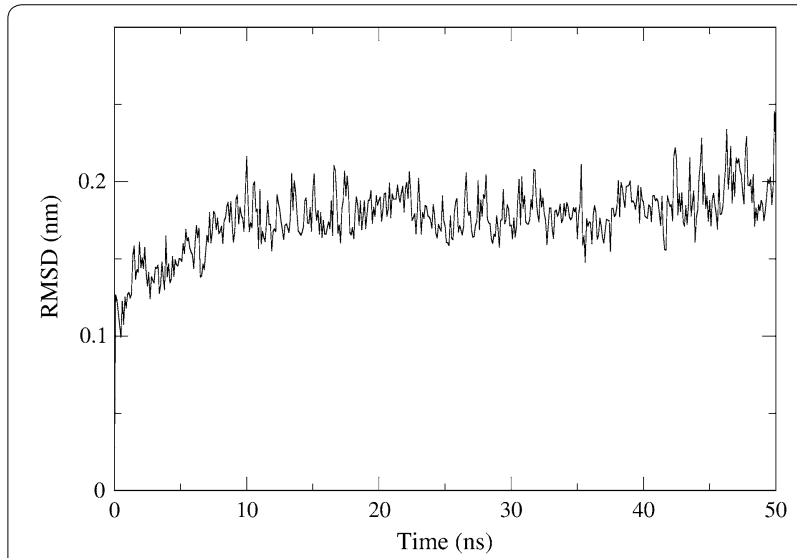

Fig. 4 RMSD values of protein backbone of STE/STE20/YSK protein kinase homology model during 50 ns MD simulation

selected as the potential target protein of our chemical structures.

\section{Homology modelling}

The 3D structure of STE/STE20/YSK protein kinase is currently not available in the Protein Data Bank (PDB). In such cases, homology modelling has been found as an effective method for 3D structure prediction of proteins. Therefore, homology modelling was performed through the Automated Comparative Protein Modelling Server (SWISS-MODEL) [34]. The STE/STE20/YSK protein kinase sequence was retrieved from Uniprot (Uniprot ID: A0A0D2XXP0). A sequence similarity search against other sequences with available structural information in PBD was applied to determine the template structure. A high resolution $(1.6 \AA)$ crystal structure of Serine/threonine-protein kinase 24 (MST3) (PDB ID: 4U8Z) was selected as template which shows $66.93 \%$ sequence identity (GMQE: 0.80 ) with the target.

The backbone of the model was validated using Ramachandran plot obtained through RAMPAGE server [35]. The Ramachandran plot for our model structure indicated that $92.1 \%$ of the residues were located in the most favourable region, $5.9 \%$ of the residues were in the allowed regions, and $2.0 \%$ of the residues were in the outlier regions. This suggests that the STE/STE20/YSK protein kinase model is of good stereo chemical quality (Fig. 2). The measurement of the structural error at each amino acid residue in the 3D structural model was measured by the ERRAT plot [36]. The overall quality factor of the model was computed as $97.38 \%$ (Fig. 3).

\section{Molecular dynamic simulation}

The validated protein model was used in the molecular dynamics simulations. Root-mean-square-deviation (RMSD) and radius of gyration (Rg) were used to check the stability of protein. The RMSD is a crucial parameter to analyse the stability of MD trajectories. To check the stability of protein during the simulation, RMSD of the protein backbone atoms were plotted as a function of time (Fig. 4). The analysis of the RMSD values indicates that the equilibration was reached after $7 \mathrm{~ns}$ simulation time.

The radius of gyration, $\mathrm{Rg}$, was also carried out to give us insight into the overall dimensions of the protein. Hence this analysis gives us the overall dimensions of the protein. The calculated Rg values over the simulation 
Table 6 Assessment of LeDock using 17 crystal structures of MST3 which have the best sequence identity with our target

\begin{tabular}{|c|c|c|c|c|c|}
\hline PDB ID & Ligand & PUBCHEM CID & $\mathrm{IC}_{50}(\mu \mathrm{M})$ & LeDock (kcal/mol) & RMSD (Å) \\
\hline $4 \mathrm{QMN}$ & Bosutinib & 5328940 & 0.003 & $-9.36 \pm 0.03$ & $2.20 \pm 0.38$ \\
\hline 4QMY & Staurosporine & 44259 & 0.004 & $-8.86 \pm 0.06$ & $0.86 \pm 0.01$ \\
\hline 4QMT & Hesperadin & 10142586 & 0.01 & $-9.86 \pm 0.04$ & $1.20 \pm 0.17$ \\
\hline $4 \mathrm{~W} 8 \mathrm{E}$ & PF-06645342 & 91623338 & 0.0121 & $-8.39 \pm 0.03$ & $1.79 \pm 0.18$ \\
\hline 4QMP & CDK1/2_Inhibitor_III & 5330812 & 0.014 & $-9.28 \pm 0.03$ & $1.76 \pm 0.12$ \\
\hline $4 \mathrm{QMO}$ & PKR_Inhibitor_C16 & 67016828 & 0.019 & $-7.64 \pm 0.02$ & $0.23 \pm 0.04$ \\
\hline 4QMV & PF-03814735 & 51346455 & 0.023 & $-9.53 \pm 0.07$ & $0.67 \pm 0.02$ \\
\hline 4QMW & PP-121 & 24905142 & 0.086 & $-8.34 \pm 0.01$ & $0.42 \pm 0.06$ \\
\hline 4Q०9 & Danusertib & 11442891 & 0.16 & $-7.86 \pm 0.01$ & $0.41 \pm 0.07$ \\
\hline $4 \cup 8 Z$ & PF-06447475 & 72706840 & 0.178 & $-7.62 \pm 0.02$ & $0.33 \pm 0.03$ \\
\hline 4QMZ & Sunitinib & 5329102 & 0.21 & $-8.54 \pm 0.05$ & $2.49 \pm 0.05$ \\
\hline 4QMQ & CP-673451 & 10158940 & 0.26 & $-8.98 \pm 0.02$ & $0.95 \pm 0.04$ \\
\hline 4QMM & AT-9283 & 11696609 & 0.46 & $-8.53 \pm 0.05$ & $1.22 \pm 0.25$ \\
\hline $4 \mathrm{QMU}$ & JNJ-7706621 & 5330790 & 1.3 & $-8.08 \pm 0.02$ & $1.20 \pm 0.77$ \\
\hline 4QMS & Dasatinib & 3062316 & 7.4 & $-8.83 \pm 0.41$ & $3.86 \pm 1.63$ \\
\hline $4 \mathrm{QMX}$ & Saracatinib & 10302451 & 11 & $-7.50 \pm 0.05$ & $1.23 \pm 0.11$ \\
\hline \multirow[t]{2}{*}{ 4QNA } & Tp-Fragment & 6806574 & 23 & $-5.50 \pm 0.06$ & $5.58 \pm 0.07$ \\
\hline & & & & $0.74 \pm 0.02^{*}$ & $78.43 \pm 3.40^{* *}$ \\
\hline
\end{tabular}

* Pearson correlation $(r)$ value calculated using the docking scores and I $C_{50}$ values

** Percent of success rate for pose prediction within the best-scored pose

time scale for the STE/STE20/YSK protein are shown in Additional file 1 . The $\mathrm{Rg}$ values were stabilized at about $5 \mathrm{~ns}$, indicating that the MD simulation achieved equilibrium after $5 \mathrm{~ns}$. The structure obtained at the end of the simulation was taken as the stabilized structure for further studies in molecular docking.

\section{Molecular docking}

Prior to molecular docking of the synthesized thiadiazole derivatives to STE/STE20/YSK protein kinase using our homology-modelled protein, the reliability and accuracy of LeDock was analysed using crystal structures of MST3 which has the best sequence identity with STE/STE20/ YSK protein kinase. Accordingly, 17 PDB structures of MST3 were downloaded from PDB database. Then, crystal binding poses, and binding affinities of native ligands were predicted using LeDock in triplicate. LeDock scores and RMSD values are listed in Table 6. According to the results, LeDock displayed $0.74 \pm 0.02$ pearson correlation (score vs $\mathrm{IC}_{50}$ ) and predicted the experimental binding mode with $78.43 \pm 3.40 \%$ (RMSD) success rate. These results suggested that LeDock can be used as a reliable docking tool for the STE/STE20/YSK protein kinase.

Finally, we performed molecular docking to our studied compounds using stabilized structure of STE/ STE20/YSK protein kinase model. Each docking was carried out in triplicate. The results are listed in Table 7. Ligands are ranked according to the $\mathrm{LD}_{50}$ values.

The Pearson correlation was also calculated. Although the scoring functions of the docking software available at the market have low success rate in discriminating between active and inactive compounds [24, 37-39] the Pearson correlation was found to be $0.63 \pm 0.03$ which shows a good agreement between experimental LD50 values and calculated docking scores.

In an effort to investigate the differences between the binding modes of the active and non-active compounds, we aligned the most two active compounds (7c and $7 \mathbf{h}$ ) and also the least two activate compounds (6d and $6 \mathbf{i}$ ) which share similar scaffolds. As can clearly be seen in Fig. 5, the most active compounds ( $7 \mathbf{c}$ and $7 \mathbf{h}$ ) adopt similar binding orientations and burry deep into 
Table 7 Docking scores, LD $_{50}$ values and calculated molecular properties of the studied compounds

\begin{tabular}{|c|c|c|c|c|c|c|c|c|c|}
\hline Comp. & $\mathrm{LD}_{50}$ & LeDock (kcal/mol) & SASA $^{\mathbf{b}}$ & QPlogPo/wc & QPlogBB $^{d}$ & QPPMDCK $^{\mathrm{e}}$ & $\% \mathrm{HOA}^{f}$ & $\mathrm{PSA}^{\mathrm{g}}$ & RoF $^{h}$ \\
\hline $7 c$ & 350.00 & $-7.2 \pm 0.06$ & 639.88 & 4.27 & -0.45 & 3068.46 & 100.00 & 65.45 & + \\
\hline $7 \mathrm{~h}$ & 398.00 & $-6.04 \pm 0.05$ & 601.82 & 4.15 & -0.25 & 5391.60 & 100.00 & 65.63 & + \\
\hline $6 n$ & 404.00 & $-6.15 \pm 0.03$ & 558.23 & 3.08 & -0.58 & 1419.32 & 95.35 & 76.58 & + \\
\hline $6 \mathrm{~m}$ & 406.00 & $-5.64 \pm 0.02$ & 506.57 & 2.56 & -0.36 & 1896.76 & 94.11 & 68.84 & + \\
\hline $7 a$ & 406.00 & $-5.77 \pm 0.06$ & 596.58 & 3.68 & -0.46 & 1942.04 & 100.00 & 67.88 & + \\
\hline 4 & 412.00 & $-5 \pm 0.02$ & 419.66 & 2.08 & -0.30 & 1654.09 & 90.79 & 55.23 & + \\
\hline $7 n$ & 418.00 & $-6.01 \pm 0.10$ & 548.66 & 2.93 & -0.66 & 1012.14 & 93.95 & 77.23 & + \\
\hline $7 b$ & 432.00 & $-6.59 \pm 0.07$ & 628.20 & 2.68 & -1.74 & 150.18 & 79.02 & 112.17 & + \\
\hline $7 e$ & 434.00 & $-6.32 \pm 0.03$ & 609.68 & 4.24 & -0.23 & 6111.44 & 100.00 & 66.82 & + \\
\hline 61 & 441.00 & $-6.72 \pm 0.04$ & 633.75 & 3.09 & -1.29 & 378.36 & 86.03 & 92.20 & + \\
\hline $7 m$ & 443.00 & $-5.82 \pm 0.02$ & 503.14 & 2.58 & -0.24 & 2684.89 & 96.42 & 67.17 & + \\
\hline $7 f^{a}$ & 453.00 & $-6.38 \pm 0.06$ & NA & NA & NA & NA & NA & NA & NA \\
\hline 71 & 453.00 & $-6.66 \pm 0.08$ & 626.86 & 3.00 & -1.23 & 395.77 & 87.00 & 93.13 & + \\
\hline $6 g$ & 474.00 & $-6.42 \pm 0.02$ & 670.74 & 4.19 & -0.50 & 2889.36 & 100.00 & 83.43 & + \\
\hline $6 \mathrm{~h}$ & 490.00 & $-6.02 \pm 0.07$ & 610.56 & 4.25 & -0.17 & 5544.37 & 100.00 & 67.79 & + \\
\hline $6 k$ & 499.00 & $-6.69 \pm 0.11$ & 696.71 & 5.10 & -0.50 & 6026.31 & 94.22 & 66.34 & - \\
\hline $6 c$ & 505.00 & $-6.9 \pm 0.07$ & 648.58 & 4.44 & -0.44 & 3600.07 & 100.00 & 66.28 & + \\
\hline $6 f$ & 508.00 & $-6.47 \pm 0.07$ & 680.55 & 4.40 & -0.39 & 4240.46 & 100.00 & 82.20 & + \\
\hline $7 g$ & 509.00 & $-6.37 \pm 0.08$ & 664.51 & 3.92 & -0.70 & 1552.70 & 100.00 & 83.28 & + \\
\hline $7 k$ & 519.00 & $-7.17 \pm 0.17$ & 639.11 & 4.70 & -0.24 & 7186.32 & 100.00 & 65.83 & + \\
\hline $6 j$ & 520.00 & $-6.34 \pm 0.09$ & 644.03 & 4.61 & -0.38 & 3203.37 & 100.00 & 66.79 & + \\
\hline $7 i$ & 522.00 & $-6.18 \pm 0.04$ & 629.94 & 4.56 & -0.10 & 8066.57 & 100.00 & 68.85 & + \\
\hline $6 a$ & 534.00 & $-6.26 \pm 0.06$ & 590.06 & 4.01 & -0.28 & 3046.60 & 100.00 & 66.24 & + \\
\hline $7 \mathbf{j}$ & 564.00 & $-6.32 \pm 0.06$ & 654.68 & 4.51 & -0.51 & 2340.98 & 100.00 & 67.50 & + \\
\hline $6 b$ & 568.00 & $-6.36 \pm 0.06$ & 640.43 & 3.03 & -1.57 & 273.80 & 82.57 & 114.02 & + \\
\hline $7 d$ & 597.00 & $-6.19 \pm 0.07$ & 632.05 & 4.56 & -0.14 & 7085.16 & 100.00 & 69.02 & + \\
\hline $6 e$ & 603.00 & $-6.69 \pm 0.04$ & 613.97 & 4.35 & -0.24 & 6419.14 & 100.00 & 66.02 & + \\
\hline $6 d$ & 642.00 & $-6.27 \pm 0.10$ & 640.40 & 4.71 & -0.15 & 7874.53 & 100.00 & 68.76 & + \\
\hline $6 i$ & 750.00 & $-6.63 \pm 0.10$ & 645.84 & 5.00 & -0.06 & $10,000.00$ & 100.00 & 68.25 & + \\
\hline 3 & 797.00 & $-5.05 \pm 0.09$ & 431.02 & 2.24 & -0.28 & 1930.57 & 91.43 & 55.58 & + \\
\hline \multicolumn{10}{|c|}{ Pearson $r 0.63 \pm 0.03$} \\
\hline
\end{tabular}

a ADMET values could not be calculated due to the steric clashes between methoxy substituents

b Total solvent accessible surface area (SASA) in square angstroms using a probe with a $1.4 \AA$ A radius (recommended value: $300.0-1000.0$ )

c Logarithm of the partition coefficient of the compound between $n$-octanol and water (recommended value $<5$ )

$d$ Predicted brain/blood partition coefficient (recommended value: -3.0 to 1.2 )

e Predicted apparent MDCK cell permeability in $\mathrm{nm} / \mathrm{sec}(<25$ poor, $>500$ great $)$

$\mathrm{f}$ Percentage of human oral absorption $(<25 \%$ is weak and $>80 \%$ is strong)

g Polar surface area (recommended value $\leq 140 \AA^{2}$ ) [40]

h Violations to the Lipinski's rule of five [41]

the binding pocket. The conformational changes in the least active compounds ( $\mathbf{6} \mathbf{d}$ and $\mathbf{6 i}$ ) prevent them to fit into the binding site which we believe results in poor binding interaction with the amino acid residues of the STE/STE20/YSK protein kinase of FOL.
Finally, as can be seen from Table 7, practically all compounds obey Lipinski's rule of five and all have drug-like pharmacokinetic profile. 


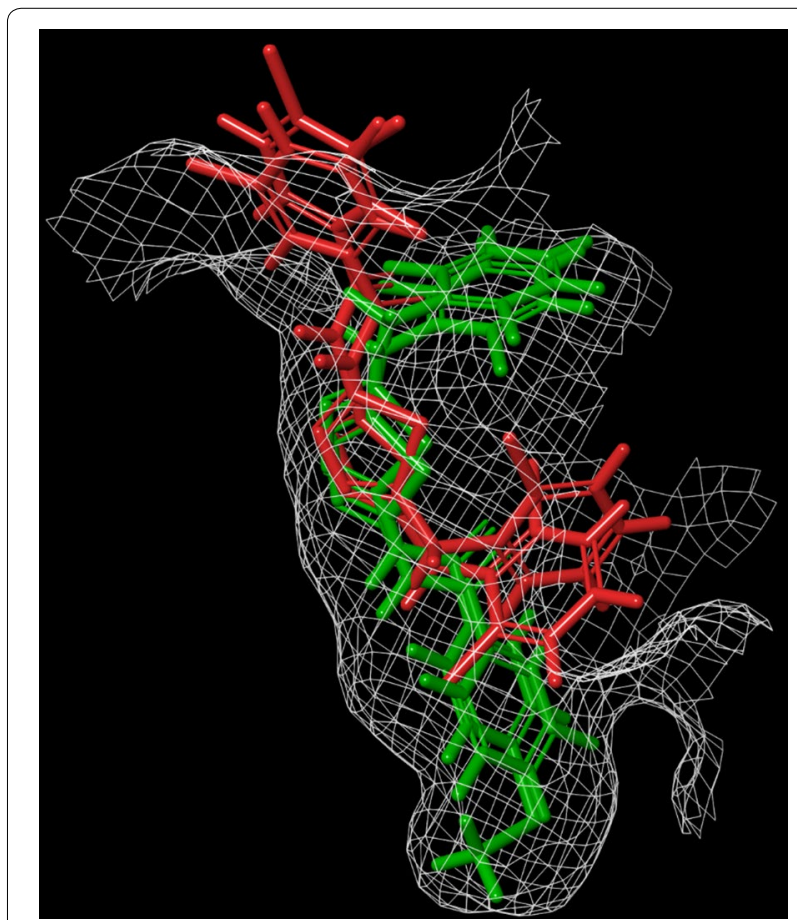

Fig. 5 Alignment of the binding conformations of the compounds $\mathbf{7 c}$, $\mathbf{7 h}$ (green) and $\mathbf{6 d}, \mathbf{6 i}$ (red). (Figure generated using Schrodinger's Maestro module) [42]

\section{Conclusion}

In the present study, 2-amino-1,3,4-thiadiazole and its acyl derivatives were synthesised with moderate to high yields using simple and applicable methods. The structures of all synthesized compounds were characterised by various spectroscopic methods such as IR, ${ }^{1} \mathrm{H}$ NMR, ${ }^{13} \mathrm{C}$ NMR, MS.

The in vitro antifungal activity of the synthesised compounds was also evaluated against plant pathogens which revealed promising activities against all tested pathogens.

The combination of several computational tools such as similarity search, homology modelling, molecular dynamics and molecular docking helped in finding a potential target, constructing its 3D model and finally enlighten a possible inhibition mechanism.

In the light of in vitro and in silico results, the studied compounds promise as antifungal candidates worthy of further development in the future.

\section{Experimental}

\section{Materials and methods}

The ${ }^{1} \mathrm{H}$ NMR and ${ }^{13} \mathrm{C}$ NMR spectra of the compounds were recorded in DMSO- $\mathrm{d}_{6}$ using an Agilent NMR VNMRS spectrometer at $400 \mathrm{MHz}$ and $100 \mathrm{MHz}$, respectively. TMS was used as an internal standard.
The IR spectra were measured in ATR using a Perkin Elmer FT-IR Spectrometer Frontier. The mass spectra were measured with a Thermo TSQ Quantum Access Max LC-MS/MS spectrometer. The elemental analysis of the compounds was performed using a LECO 932 CHNS device and the results were within $\pm 0.4 \%$ of the theoretical values. Melting points were recorded on a Thermo Scientific IA9000 series apparatus and were uncorrected. All of the chemicals were obtained from Sigma-Aldrich Chemicals.

\section{General synthesis of 2-amino-1,3,4-thiadiazole derivatives $(3,4)$}

In a round-bottomed flask, compounds 1 or $2(0.075 \mathrm{~mol})$ and thiosemicarbazide $(0.100 \mathrm{~mol})$ in trifluoroacetic acid $(5 \mathrm{ml})$ at $60{ }^{\circ} \mathrm{C}$ were stirred for $3-5 \mathrm{~h}$. After completion of the reaction, the reaction mixture was poured into $250 \mathrm{ml}$ ice-water mixture and neutralized with diluted ammonia. The solution was filtered, and solid substance was obtained. The solid substance was washed with water, ethyl alcohol, and diethyl ether, respectively. The solid was recrystallized from the appropriate solvent. The pure substance is dried with $\mathrm{P}_{2} \mathrm{O}_{5}$ vacuum oven. Finally, the structures of the synthesized compounds were elucidated with FT-IR, ${ }^{1} \mathrm{H}$ NMR, ${ }^{13} \mathrm{C}$ NMR, mass spectroscopy, and elemental analysis. The spectral data and the physical properties of the products are listed below.

\section{5-(2,6-Dichlorobenzyl)-1,3,4-thiadiazol-2-amine (3)}

White solid, yield: $15.79 \mathrm{~g}(81 \%)$, m.p. $219-220{ }^{\circ} \mathrm{C}$ (DMFEtOH, 1:5). IR (ATR, $\left.\mathrm{cm}^{-1}\right): 3258-3098\left(-\mathrm{NH}_{2}\right), 3080$ (Ar-CH), 2976 (Aliphatic $\mathrm{CH}), 1582(\mathrm{C}=\mathrm{N}) .{ }^{1} \mathrm{H}$ NMR $\left(400 \mathrm{MHz}, \mathrm{DMSO}-\mathrm{d}_{6}\right) \delta(\mathrm{ppm}): 4.40\left(\mathrm{~s}, 2 \mathrm{H},-\mathrm{CH}_{2}\right)$, Arom- $\mathrm{H}[7.49(\mathrm{~d}, J=7.8 \mathrm{~Hz}, 2 \mathrm{H}), 7.36(\mathrm{t}, J=7.8 \mathrm{~Hz}, 1 \mathrm{H})]$, 7.69 (bs, $\left.2 \mathrm{H}, \mathrm{NH}_{2}\right) \cdot{ }^{13} \mathrm{C}$ NMR $\left(400 \mathrm{MHz}, \mathrm{DMSO}_{-} \mathrm{d}_{6}, \delta\right.$ ppm): $32.16\left(-\mathrm{CH}_{2}\right)$, Arom-C [129.09 $(\mathrm{CH}), 130.49(\mathrm{CH})$, 133.40 (C), 135.44 (C)], Thiadiazole-C [154.37 (C), 169.39 (C)]. Anal. Calcd. for $\mathrm{C}_{9} \mathrm{H}_{7} \mathrm{Cl}_{2} \mathrm{~N}_{3} \mathrm{~S}$ : C, 41.55; H, 2.71; N, 16.15. Found: C, 41.43; H, 2.76; N, 15.99. MS: $m / z 260$ $\left(\mathrm{M}^{+}, 74\right) ; 261(\mathrm{M}+1,51)$.

\section{5-(2-Chloro-6-fluorobenzyl)-1,3,4-thiadiazole-2-amine (4)}

White solid, yield: $15.35 \mathrm{~g}$ (84\%), m.p. $212-213{ }^{\circ} \mathrm{C}$ (DMFEtOH, 1:6). IR (ATR, $\left.\mathrm{cm}^{-1}\right): 3261-3106\left(-\mathrm{NH}_{2}\right), 3067$ $($ Ar- $\mathrm{CH}), 2968$ (Aliphatic $\mathrm{CH}), 1597(\mathrm{C}=\mathrm{N}) .{ }^{1} \mathrm{H}$ NMR $\left(400 \mathrm{MHz}, \mathrm{DMSO}-\mathrm{d}_{6}\right) \delta(\mathrm{ppm}): 4.25\left(\mathrm{~s}, 2 \mathrm{H},-\mathrm{CH}_{2}\right)$, Arom-H $[7.35(\mathrm{~d}, J=12.0 \mathrm{~Hz}, 2 \mathrm{H}), 7.25(\mathrm{t}, J=7.8 \mathrm{~Hz}$, 1H)], 7.08 (bs, $2 \mathrm{H}, \mathrm{NH}_{2}$ ). ${ }^{13} \mathrm{C}$ NMR $(400 \mathrm{MHz}$, DMSO$\left.\mathrm{d}_{6}, \delta \mathrm{ppm}\right): 27.34\left(-\mathrm{CH}_{2}\right)$, Arom-C [115.12 $(\mathrm{CH}), 123.98$ $(\mathrm{CH}), 125.98(\mathrm{C}), 130.44(\mathrm{C}), 134.80(\mathrm{CH}), 160.02(\mathrm{C})]$, Thiadiazole-C [154.52 (C), 169.21 (C)]. Anal. Calcd. for $\mathrm{C}_{9} \mathrm{H}_{7} \mathrm{ClFN}_{3} \mathrm{~S}: \mathrm{C}, 44.36 ; \mathrm{H}, 2.90 ; \mathrm{N}, 17.24$. Found: $\mathrm{C}, 44.43$; $\mathrm{H}, 2.87$; N, 17.17. MS: $m / z 243.73\left(\mathrm{M}^{+}, 100\right)$. 


\section{General acylation reactions of 2-amino-1,3,4-thiadiazole derivatives ( $6 a-n, 7 a-n)$}

In a two-necked flask, compounds 3 or $4(0.004 \mathrm{~mol})$ were solved in dry benzene $(40 \mathrm{ml})$ and added pyridine $(1 \mathrm{ml})$ to this solution. Acyl chloride derivatives $(\mathbf{5 a}-\mathbf{n})$ $(0.004 \mathrm{~mol})$ were added drop-wise to this solution at room temperature with the assistance of a dropping funnel. The mixture was then refluxed and stirred for 4-6 h. The progress of the reaction was monitored by TLC at appropriate time intervals. After completion of the reaction, the solution was filtered, and the solid matter was obtained. It was washed with deionized water, ethanol and diethyl ether, respectively. The solid matter was recrystallized from the appropriate solvent. All physical properties and spectral data derived from the obtained products are given below.

\section{N-(5-(2,6-Dichlorobenzyl)-1,3,4-thiadiazol-2-yl)benzamide (6a)}

White solid, yield: $1.14 \mathrm{~g}$ (78\%), m.p. $279-280{ }^{\circ} \mathrm{C}$ (DMFEtOH, 1:1). IR (ATR, cm $\left.{ }^{-1}\right): 3169$ (-NH-), 3061 (Ar$\mathrm{CH}), 2983$ (Aliphatic $\mathrm{CH}), 1667(\mathrm{C}=\mathrm{O}), 1582(\mathrm{C}=\mathrm{N}) .{ }^{1} \mathrm{H}$ NMR (400 MHz, DMSO-d $\left.{ }_{6}\right) \delta(\mathrm{ppm}): 4.62\left(\mathrm{~s}, 2 \mathrm{H},-\mathrm{CH}_{2}\right)$, Arom-H $[8.06(\mathrm{~d}, J=6.4 \mathrm{~Hz}, 2 \mathrm{H}), 7.61(\mathrm{~d}, J=6.0 \mathrm{~Hz}, 1 \mathrm{H})$, 7.54 (bs, 2H), 7.52 (bs, 2H), 7.39 (t, J=7.6 Hz, 1H)], 12.99 (s, $1 \mathrm{H}, \mathrm{NH}) .{ }^{13} \mathrm{C}$ NMR (400 MHz, DMSO-d $\left.6, \delta \mathrm{ppm}\right)$ : $31.80\left(-\mathrm{CH}_{2}\right)$, Arom-C [128.80 (CH), $129.08(\mathrm{CH}), 129.22$ $(\mathrm{CH}), 130.64(\mathrm{CH}), 131.90(\mathrm{CH}), 133.41(\mathrm{C}), 134.64$ (C), 135.52 (C)], Thiadiazole-C [159.86 (C), $160.84(\mathrm{C})]$, $165.53 \mathrm{C}=\mathrm{O}$. Anal. Calcd. for $\mathrm{C}_{16} \mathrm{H}_{11} \mathrm{Cl}_{2} \mathrm{~N}_{3} \mathrm{OS}$ : C, 52.76; $\mathrm{H}, 3.04 ; \mathrm{N}, 11.54$. Found: C, 52.68; H, 3.00; N, 11.41. MS: $m / z: 363.68$ (M-1, 100), $365.85(\mathrm{M}+1,84)$.

\section{N-(5-(2,6-Dichlorobenzyl)-1,3,4-thiadiazol-2-yl)-4-nitroben- zamide (6b)}

White solid, yield: 1.21 g (74\%), m.p. $320-321{ }^{\circ} \mathrm{C}$ (DMF$\mathrm{EtOH}, 1: 15)$. IR (ATR, $\mathrm{cm}^{-1}$ ): 3133 (-NH-), 3044 (Ar$\mathrm{CH}), 2930$ (Aliphatic $\mathrm{CH}), 1677(\mathrm{C}=\mathrm{O}), 1596(\mathrm{C}=\mathrm{N})$. ${ }^{1} \mathrm{H}$ NMR (400 MHz, DMSO-d 6 ) $\delta$ (ppm): 4.62 (s, 2H, $\mathrm{CH}_{2}$ ), Arom-H [8.29 (d, 4H), 7.53 (bs, 2H), 7.39 (bs, 1H)], $13.40(\mathrm{~s}, 1 \mathrm{H}, \mathrm{NH}) .{ }^{13} \mathrm{C}$ NMR (400 MHz, DMSO-d ${ }_{6}, \delta$ ppm): $31.80\left(-\mathrm{CH}_{2}\right)$, Arom-C [124.09 $(\mathrm{CH}), 126.64(\mathrm{CH})$, $129.23(\mathrm{CH}), 130.41(\mathrm{CH}), 133.57(\mathrm{C}), 135.51(\mathrm{C}), 139.82$ (C), $150.33(\mathrm{C})]$, Thiadiazole-C [159.88 (C), 160.81 (C)], $165.40 \mathrm{C}=\mathrm{O}$. Anal. Calcd. for $\mathrm{C}_{16} \mathrm{H}_{10} \mathrm{Cl}_{2} \mathrm{~N}_{4} \mathrm{O}_{3} \mathrm{~S}: \mathrm{C}$, 46.96; H, 2.46; N, 13.69. Found: C, 46.88; H, 2.59; N, 13.562. MS: $m / z: 408.93\left(\mathrm{M}^{+}, 100\right), 410.96(\mathrm{M}+1,93)$.

\section{N-(5-(2,6-Dichlorobenzyl)-1,3,4-thiadia-} zol-2-yl)-4-(methylthio)benzamide (6c)

White solid, yield: 1.13 g (69\%), m.p. $282-283{ }^{\circ} \mathrm{C}$ (DMFEtOH, 1:1). IR (ATR, cm $\left.{ }^{-1}\right): 3132$ (-NH-), 3035 (Ar$\mathrm{CH}), 2921$ (Aliphatic $\mathrm{CH}), 1674(\mathrm{C}=\mathrm{O}), 1595(\mathrm{C}=\mathrm{N})$.
${ }^{1} \mathrm{H}$ NMR (400 MHz, DMSO-d $\left.{ }_{6}\right) \delta$ (ppm): $2.48(\mathrm{t}, 3 \mathrm{H},-$ $\left.\mathrm{CH}_{3}\right), 4.61\left(\mathrm{~s}, 2 \mathrm{H},-\mathrm{CH}_{2}\right)$, Arom- $\mathrm{H}[8.00(\mathrm{~d}, J=8.0 \mathrm{~Hz}$, $2 \mathrm{H}), 7.54(\mathrm{~d}, J=8.4 \mathrm{~Hz}, 2 \mathrm{H}), 7.37(\mathrm{~m}, 3 \mathrm{H})], 12.90(\mathrm{~s}, 1 \mathrm{H}$, $\mathrm{NH}),{ }^{13} \mathrm{C}$ NMR (400 MHz, DMSO-d $\left.\mathrm{d}_{6} \delta \mathrm{ppm}\right): 14.95$ $\left(\mathrm{CH}_{3}\right), 31.79\left(-\mathrm{CH}_{2}\right)$, Arom-C [125.32 $(\mathrm{CH}), 127.54(\mathrm{CH})$, $129.22(\mathrm{CH}), 130.64(\mathrm{CH}), 133.66(\mathrm{C}), 135.52(\mathrm{C}), 139.63$ (C), $145.70(\mathrm{C})]$, Thiadiazole-C [160.46 (C), 163.66 (C)], 165.63 C=O. Anal. Calcd. for $\mathrm{C}_{17} \mathrm{H}_{13} \mathrm{Cl}_{2} \mathrm{~N}_{3} \mathrm{OS}_{2}$ : C, 49.76; $\mathrm{H}, 3.19$; N, 10.24. Found: C, 49.68; H, 3.06; N, 10.12. MS $(\mathrm{ESI}-m / z): 411.38(\mathrm{M}+1,76), 413.34(\mathrm{M}+2,48)$.

\section{N-(5-(2,6-Dichlorobenzyl)-1,3,4-thiadiazol-2-yl)-3,4-dich-}

\section{lorobenzamide (6d)}

White solid, yield: 1.25 g (73\%), m.p. $295-296{ }^{\circ} \mathrm{C}$ (DMFEtOH, 1:15). IR (ATR, cm $\left.{ }^{-1}\right): 3142$ (-NH-), 3084 (Ar$\mathrm{CH}), 2967$ (Aliphatic $\mathrm{CH}), 1682(\mathrm{C}=\mathrm{O}), 1560(\mathrm{C}=\mathrm{N})$. ${ }^{1} \mathrm{H}$ NMR (400 MHz, DMSO-d $\left.{ }_{6}\right) \delta(\mathrm{ppm}): 4.62(\mathrm{~s}, 2 \mathrm{H}$, $\left.-\mathrm{CH}_{2}\right)$, Arom-H [8.30 (s, $\left.1 \mathrm{H}\right), 7.99(\mathrm{~d}, J=8.0 \mathrm{~Hz}, 1 \mathrm{H})$, $7.80(\mathrm{~d}, J=8.4 \mathrm{~Hz}, 1 \mathrm{H}), 7.53(\mathrm{~d}, J=8.0 \mathrm{~Hz}, 2 \mathrm{H}), 7.38$ $(\mathrm{t}, J=8.0,7.2 \mathrm{~Hz}, 1 \mathrm{H})], 13.15(\mathrm{~s}, 1 \mathrm{H}, \mathrm{NH}) .{ }^{13} \mathrm{C} \mathrm{NMR}$ (400 MHz, DMSO-d $6, \delta$ ppm): $31.84\left(-\mathrm{CH}_{2}\right)$, Arom-C [129.05 (CH), $129.22(\mathrm{CH}), 129.97(\mathrm{CH}), 130.68(\mathrm{CH})$, $130.76(\mathrm{CH}), 131.42(\mathrm{C}), 131.98(\mathrm{C}), 133.54(\mathrm{C}), 135.51$ (C), $136.16(\mathrm{C})]$, Thiadiazole-C [159.85 (C), 160.96 (C)], 166.16 C=O. Anal. Calcd. for $\mathrm{C}_{16} \mathrm{H}_{9} \mathrm{Cl}_{4} \mathrm{~N}_{3} \mathrm{OS}: \mathrm{C}$, 44.37; H, 2.09; N, 9.70. Found: C, 44.23; H, 2.01; N, 9.57. MS $(\mathrm{ESI}-m / z): 433.71(\mathrm{M}+1,100)$.

\section{N-(5-(2,6-Dichlorobenzyl)-1,3,4-thiadiazol-2-yl)-3,4-dif- luorobenzamide (6e)}

White solid, yield: 1.30 g (80\%), m.p. $304-305{ }^{\circ} \mathrm{C}$ (DMF-EtOH, 1:15). IR (ATR, $\left.\mathrm{cm}^{-1}\right): 3142$ (-NH-), 3087 (Ar-CH), 2941 (Aliphatic CH), 1663 (C=O), 1563 $(\mathrm{C}=\mathrm{N}) .{ }^{1} \mathrm{H}$ NMR $\left(400 \mathrm{MHz}, \mathrm{DMSO}-\mathrm{d}_{6}\right) \delta(\mathrm{ppm}): 4.61$ $\left(\mathrm{s}, 2 \mathrm{H},-\mathrm{CH}_{2}\right)$, Arom-H [8.13 (t, $\left.1 \mathrm{H}\right), 7.95(\mathrm{~s}, 1 \mathrm{H}), 7.60$ $(\mathrm{q}, 1 \mathrm{H}), 7.53(\mathrm{~d}, J=8.4 \mathrm{~Hz}, 2 \mathrm{H}), 7.38(\mathrm{t}, J=8.0,8.0 \mathrm{~Hz}$, $1 \mathrm{H})], 13.09$ (s, 1H, NH). ${ }^{13} \mathrm{C}$ NMR (400 MHz, DMSO$\left.\mathrm{d}_{6}, \delta \mathrm{ppm}\right): 31.82\left(-\mathrm{CH}_{2}\right)$, Arom-C [118.32 $(\mathrm{CH}), 126.65$ $(\mathrm{CH}), 129.21(\mathrm{CH}), 130.65(\mathrm{CH}), 133.54(\mathrm{CH}), 135.51$ (C), 148.33 (C), 150.91 (C), 151.47 (C), $154.11(\mathrm{C})]$, Thiadiazole-C [159.80 (C), $161.90(\mathrm{C})$ ], $163.80 \mathrm{C}=\mathrm{O}$. Anal. Calcd. for $\mathrm{C}_{16} \mathrm{H}_{9} \mathrm{Cl}_{2} \mathrm{~F}_{2} \mathrm{~N}_{3} \mathrm{OS}$ : C, 48.02; H, 2.27; N, 10.50 . Found: $\mathrm{C}, 48.11 ; \mathrm{H}, 2.12 ; \mathrm{N}, 10.36$. MS $(\mathrm{ESI}-m / z)$ : $400.00\left(\mathrm{M}^{+}, 94\right), 402.26(\mathrm{M}+2,54)$.

\section{N-(5-(2,6-Dichlorobenzyl)-1,3,4-thiadiazol-2-yl)-3,4-dimeth-} oxybenzamide (6f)

White solid, yield: 1.07 g (64\%), m.p. 252-253 ${ }^{\circ} \mathrm{C}$ (DMF-EtOH, 1:1). IR (ATR, $\mathrm{cm}^{-1}$ ): 3155 (-NH-), 3047 (Ar-CH), 2941 (Aliphatic CH), $1661(\mathrm{C}=\mathrm{N}), 1587$ $(\mathrm{C}=\mathrm{N}) .{ }^{1} \mathrm{H}$ NMR $(400 \mathrm{MHz}$, DMSO-d 6 ) $\delta(\mathrm{ppm}): 3.82$ $\left(\mathrm{s}, 6 \mathrm{H},-\mathrm{OCH}_{3}\right), 4.60\left(\mathrm{~s}, 2 \mathrm{H},-\mathrm{CH}_{2}\right)$, Arom-H [7.71 
(s, 2H), 7.52 (s, 2H), 7.37 (s, 1H), $7.08(\mathrm{~s}, 1 \mathrm{H})], 12.82$ $(\mathrm{s}, 1 \mathrm{H}, \mathrm{NH}) .{ }^{13} \mathrm{C}$ NMR $\left(400 \mathrm{MHz}, \mathrm{DMSO}-\mathrm{d}_{6}, \delta \mathrm{ppm}\right)$ : $31.76\left(-\mathrm{CH}_{2}\right), 56.10\left(-\mathrm{OCH}_{3}\right), 56.17\left(-\mathrm{OCH}_{3}\right)$, Arom-C [111.59 (CH), $122.85(\mathrm{CH}), 123.66(\mathrm{CH}), 129.19(\mathrm{CH})$, 130.59 (C), $133.68(\mathrm{CH}), 135.51(\mathrm{C}), 148.81(\mathrm{C}), 153.17$ (C), 160.13 (C)], Thiadiazole-C [160.59 (C), 162.74 (C)], $164.73 \mathrm{C}=\mathrm{O}$. Anal. Calcd. for $\mathrm{C}_{18} \mathrm{H}_{15} \mathrm{Cl}_{2} \mathrm{~N}_{3} \mathrm{O}_{3} \mathrm{~S}: \mathrm{C}$, $50.95 ; \mathrm{H}, 3.56 ; \mathrm{N}, 9.90$. Found: $\mathrm{C}, 50.78 ; \mathrm{H}, 3.46 ; \mathrm{N}, 9.78$. MS (ESI- $m / z): 423.91\left(\mathrm{M}^{+}, 100\right), 425.87(\mathrm{M}+2,66)$.

N-(5-(2,6-Dichlorobenzyl)-1,3,4-thiadiazol-2-yl)-3,5-dimethoxybenzamide (6g)

White solid, yield: 1.00 g (59\%), m.p. $204-205{ }^{\circ} \mathrm{C}$ (DMFEtOH, 1:1). IR (ATR, cm $\left.{ }^{-1}\right): 3138(-\mathrm{NH}-), 3032(\mathrm{Ar}-$ $\mathrm{CH}), 2959$ (Aliphatic $\mathrm{CH}), 1683(\mathrm{C}=\mathrm{O}), 1596(\mathrm{C}=\mathrm{N})$. ${ }^{1} \mathrm{H}$ NMR (400 MHz, DMSO-d 6 ) $\delta$ (ppm): 3.76 (s, 6H, $\left.\mathrm{OCH}_{3}\right), 4.39\left(\mathrm{~s}, 2 \mathrm{H},-\mathrm{CH}_{2}\right)$, Arom-H $[7.49(\mathrm{~d}, J=8.0 \mathrm{~Hz}$, $2 \mathrm{H}), 7.34(\mathrm{t}, J=8.0,7.6 \mathrm{~Hz}, 1 \mathrm{H}), 7.04(\mathrm{~s}, 2 \mathrm{H}), 6.71(\mathrm{~s}, 1 \mathrm{H})]$, 13.01 (bs, $1 \mathrm{H}, \mathrm{NH}) .{ }^{13} \mathrm{C} \mathrm{NMR}\left(400 \mathrm{MHz}, \mathrm{DMSO}-\mathrm{d}_{6}, \delta\right.$ ppm): $31.76\left(-\mathrm{CH}_{2}\right), 56.09\left(-\mathrm{OCH}_{3}\right), 56.16\left(-\mathrm{OCH}_{3}\right)$, Arom-C [107.89 (CH), $109.73(\mathrm{CH}), 129.17(\mathrm{CH}), 130.59$ $(\mathrm{CH}), 133.64(\mathrm{C}), 135.53(\mathrm{C}), 146.41(\mathrm{C}), 160.48(\mathrm{C})]$, Thiadiazole-C [153.18 (C), 162.75 (C)], $164.33 \mathrm{C}=\mathrm{O}$. Anal. Calcd. for $\mathrm{C}_{18} \mathrm{H}_{15} \mathrm{Cl}_{2} \mathrm{~N}_{3} \mathrm{O}_{3} \mathrm{~S}$ : C, 50.95; H, 3.56; N, 9.90. Found: C, 50.79; H, 3.50; N, 9.81. MS (ESI-m/z): 423.91 $\left(\mathrm{M}^{+}, 100\right)$.

\section{N-(5-(2,6-Dichlorobenzyl)-1,3,4-thiadiazol-2-yl)-3,5-dif- luorobenzamide (6h)}

White solid, yield: 1.18 g (74\%), m.p. $270-271{ }^{\circ} \mathrm{C}$ (DMFEtOH, 1:1). IR (ATR, cm $\left.{ }^{-1}\right): 3147$ (-NH-), 3044 (Ar$\mathrm{CH}), 2928$ (Aliphatic $\mathrm{CH}), 1679(\mathrm{C}=\mathrm{O}), 1595(\mathrm{C}=\mathrm{N})$. ${ }^{1} \mathrm{H}$ NMR (400 MHz, DMSO-d 6 ) $\delta$ (ppm): 4.62 (s, 2H, $\mathrm{CH}_{2}$ ), Arom-H [7.76 (s, 2H), $\left.7.54(\mathrm{bd}, 3 \mathrm{H}), 7.39(\mathrm{t}, 1 \mathrm{H})\right]$, 13.16 (s, $1 \mathrm{H}, \mathrm{NH}) .{ }^{13} \mathrm{C}$ NMR (400 MHz, DMSO-d $\mathrm{d}_{6}, \delta$ ppm): $31.84\left(-\mathrm{CH}_{2}\right)$, Arom-C [108.80 $(\mathrm{CH}), 112.24(\mathrm{CH})$, $112.43(\mathrm{C}), 129.22(\mathrm{CH}), 130.68(\mathrm{CH}), 133.51(\mathrm{C}), 135.51$ (C), 163.80 (C)], Thiadiazole-C [161.35 (C), $161.48(\mathrm{C})]$, $164.93 \mathrm{C}=\mathrm{O}$. Anal. Calcd. for $\mathrm{C}_{16} \mathrm{H}_{9} \mathrm{Cl}_{2} \mathrm{~F}_{2} \mathrm{~N}_{3} \mathrm{OS}: \mathrm{C}$, 48.02; $\mathrm{H}, 2.27$; N, 10.50. Found: C, 47.96; H, 2.20; N, 10.56. MS $(\mathrm{ESI}-m / z): 399.80(\mathrm{M}-1,100), 401.83(\mathrm{M}+1,74)$.

\section{N-(5-(2,6-Dichlorobenzyl)-1,3,4-thiadiazol-2-yl)-3,5-dich- lorobenzamide (6i)}

White solid, yield: 1.33 g (77\%), m.p. $260-261{ }^{\circ} \mathrm{C}$ (DMFEtOH, 1:1). IR (ATR, cm $\left.{ }^{-1}\right): 3147$ (-NH-), 3070 (Ar$\mathrm{CH}), 2969$ (Aliphatic $\mathrm{CH}), 1663(\mathrm{C}=\mathrm{O}), 1563(\mathrm{C}=\mathrm{N}) .{ }^{1} \mathrm{H}$ NMR (400 MHz, DMSO-d $\left.{ }_{6}\right) \delta(\mathrm{ppm}): 4.62\left(\mathrm{~s}, 2 \mathrm{H},-\mathrm{CH}_{2}\right)$, Arom-H [8.06 (s, 2H), $7.89(\mathrm{~s}, 1 \mathrm{H}), 7.54(\mathrm{~d}, J=8.0 \mathrm{~Hz}$, $2 \mathrm{H}), 7.39(\mathrm{t}, J=8.0,7.6 \mathrm{~Hz}, 1 \mathrm{H})], 13.16(\mathrm{~s}, 1 \mathrm{H}, \mathrm{NH}) .{ }^{13} \mathrm{C}$ NMR (400 MHz, DMSO-d $\left.{ }_{6}, \delta \mathrm{ppm}\right): 31.87\left(-\mathrm{CH}_{2}\right)$, Arom-C [127.60 (CH), $129.22(\mathrm{CH}), 130.69(\mathrm{C}), 132.50$ (CH), 133.50 (C), 134.90 (C), 135.47 (C), 135.52 (C)],
Thiadiazole-C [160.08 (C), 162.54 (C)], $163.93 \mathrm{C}=\mathrm{O}$. Anal. Calcd. for $\mathrm{C}_{16} \mathrm{H}_{9} \mathrm{Cl}_{4} \mathrm{~N}_{3} \mathrm{OS}$ : C, 44.37; H, 2.09; N, 9.70. Found: C, 44.22; H, 2.18; N, 9.52. MS (ESI-m/z): 431.79 $(\mathrm{M}-1,76)$.

\section{N-(5-(2,6-Dichlorobenzyl)-1,3,4-thiadiazol-2-yl)-4-ethylben- zamide (6j)}

White solid, yield: 1.02 g (65\%), m.p. $275-276{ }^{\circ} \mathrm{C}$ (DMFEtOH, 1:1). IR (ATR, cm $\left.{ }^{-1}\right): 3184(-\mathrm{NH}-), 3059$ (Ar$\mathrm{CH}), 2964$ (Aliphatic $\mathrm{CH}), 1662(\mathrm{C}=\mathrm{O}), 1576(\mathrm{C}=\mathrm{N})$. ${ }^{1} \mathrm{H}$ NMR (400 MHz, DMSO-d 6 ) $\delta(\mathrm{ppm}): 1.17$ (t, 3H, $\left.\mathrm{CH}_{3}\right), 2.65\left(\mathrm{q}, 2 \mathrm{H},-\mathrm{CH}_{2}-\right), 4.61\left(\mathrm{~s}, 2 \mathrm{H},-\mathrm{CH}_{2}\right)$, Arom-H [7.99 (d, $J=8.0 \mathrm{~Hz}, 2 \mathrm{H}), 7.54(\mathrm{~d}, J=8.4 \mathrm{~Hz}, 2 \mathrm{H}), 7.36(\mathrm{~m}$, $3 \mathrm{H})$ ], 12.87 (s, 1H, NH). ${ }^{13} \mathrm{C}$ NMR (400 MHz, DMSO$\left.\mathrm{d}_{6}, \delta \mathrm{ppm}\right): 15.61\left(-\mathrm{CH}_{3}\right), 28.58\left(-\mathrm{CH}_{2}-\right), 31.79\left(-\mathrm{CH}_{2}\right)$, Arom-C [128.47 (CH), $128.95(\mathrm{CH}), 129.01(\mathrm{CH}), 129.21$ $(\mathrm{CH}), 130.62(\mathrm{C}), 133.66(\mathrm{C}), 135.52(\mathrm{C}), 149.83(\mathrm{C})]$, Thiadiazole-C [159.65 (C), $160.72(\mathrm{C})], 165.40 \mathrm{C}=\mathrm{O}$. Anal. Calcd. for $\mathrm{C}_{18} \mathrm{H}_{15} \mathrm{Cl}_{2} \mathrm{~N}_{3} \mathrm{OS}$ : C, 55.11; H, 3.85; N, 10.71 . Found: C, 55.02; H, 3.79; N, 10.63. MS (ESI-m/z): 393.77 $(\mathrm{M}+1,93)$.

\section{N-(5-(2,6-Dichlorobenzyl)-1,3,4-thiadia- zol-2-yl)-4-(trifluoromethyl)benzamide (6k)}

White solid, yield: 1.07 g (62\%), m.p. 274-275 ${ }^{\circ} \mathrm{C}$ (DMFEtOH, 1:1). IR (ATR, $\left.\mathrm{cm}^{-1}\right): 3152(-\mathrm{NH}-), 3041$ (Ar$\mathrm{CH}), 2943$ (Aliphatic $\mathrm{CH}), 1680(\mathrm{C}=\mathrm{O}), 1531(\mathrm{C}=\mathrm{N}) .{ }^{1} \mathrm{H}$ NMR (400 MHz, DMSO-d $\left.{ }_{6}\right) \delta$ (ppm): $4.63\left(\mathrm{~s}, 2 \mathrm{H},-\mathrm{CH}_{2}\right)$, Arom-H [8.23 (d, J=8.0 Hz, 2H), $7.90(\mathrm{~d}, J=8.4 \mathrm{~Hz}, 2 \mathrm{H})$, $7.54(\mathrm{~d}, J=8.4 \mathrm{~Hz}, 2 \mathrm{H}), 7.39$ (t, $J=7.6,7.6 \mathrm{~Hz}, 1 \mathrm{H})], 13.26$ (s, $1 \mathrm{H}, \mathrm{NH}) .{ }^{13} \mathrm{C}$ NMR (400 MHz, DMSO-d 6 , $\left.\delta \mathrm{ppm}\right)$ : $31.84\left(-\mathrm{CH}_{2}\right), 122.84\left(\mathrm{CF}_{3}\right)$, Arom-C [125.56 $(\mathrm{CH}), 125.99$ $(\mathrm{CH}), 126.03(\mathrm{CH}), 129.22(\mathrm{CH}), 129.78(\mathrm{C}), 130.68(\mathrm{C})$, $133.56(\mathrm{C}), 135.52(\mathrm{C})$ ], Thiadiazole-C [159.86 (C), 160.84 (C) ], $165.53 \mathrm{C}=\mathrm{O}$. Anal. Calcd. for $\mathrm{C}_{17} \mathrm{H}_{10} \mathrm{Cl}_{2} \mathrm{~F}_{3} \mathrm{~N}_{3} \mathrm{OS}$ : C, 47.24; H, 2.33; N, 9.72. Found: C, 47.36; H, 2.26; N, 9.65. MS (ESI- $m / z)$ : 431.86 (M-1, 82).

\section{N-(5-(2,6-Dichlorobenzyl)-1,3,4-thiadiazol-2-yl)-4-cyanoben-}

\section{zamide (6I)}

White solid, yield: 1.26 g (81\%), m.p. $334-335{ }^{\circ} \mathrm{C}$ (DMFEtOH, 1:1). IR (ATR, cm $\left.{ }^{-1}\right): 3142(-\mathrm{NH}-)$, 3094 (Ar$\mathrm{CH}), 2921$ (Aliphatic $\mathrm{CH}), 2235(\mathrm{CN}), 1684(\mathrm{C}=\mathrm{O}), 1542$ $(\mathrm{C}=\mathrm{N}) .{ }^{1} \mathrm{H}$ NMR $\left(400 \mathrm{MHz}, \mathrm{DMSO}-\mathrm{d}_{6}\right) \delta(\mathrm{ppm}): 4.63$ $\left(\mathrm{s}, 2 \mathrm{H},-\mathrm{CH}_{2}\right)$, Arom-H $[8.18(\mathrm{~d}, J=8.4 \mathrm{~Hz}, 2 \mathrm{H}), 8.01$ (d, $J=8.0 \mathrm{~Hz}, 2 \mathrm{H}), 7.54(\mathrm{~d}, J=8.4 \mathrm{~Hz}, 2 \mathrm{H}), 7.38(\mathrm{t}, J=8.0$, $8.0 \mathrm{~Hz}, 1 \mathrm{H})], 13.27(\mathrm{~s}, 1 \mathrm{H}, \mathrm{NH}) .{ }^{13} \mathrm{C} \mathrm{NMR}(400 \mathrm{MHz}$, DMSO-d $\left.{ }_{6}, \delta \mathrm{ppm}\right): 31.86\left(-\mathrm{CH}_{2}\right), 118.56(\mathrm{CN})$, AromC $[115.40(\mathrm{C}), 125.54(\mathrm{CH}), 129.23(\mathrm{CH}), 129.61(\mathrm{CH})$, $130.70(\mathrm{CH}), 133.03(\mathrm{C}), 133.53(\mathrm{C}), 135.52(\mathrm{C})]$, Thiadiazole-C [159.88 (C), 160.86 (C)], $165.80 \mathrm{C}=\mathrm{O}$. Anal. Calcd. for $\mathrm{C}_{17} \mathrm{H}_{10} \mathrm{Cl}_{2} \mathrm{~N}_{4} \mathrm{OS}$ : C, 52.45; H, 2.59; N, 14.39 . 
Found: C, 52.36; H, 2.46; N, 14.50. MS (ESI- $m / z): 385.22$ $(\mathrm{M}-4,100)$.

\section{N-(5-(2,6-Dichlorobenzyl)-1,3,4-thiadiazol-2-yl)acetamide (6m)}

White solid, yield: 1.03 g (83\%), m.p. 284-285 ${ }^{\circ} \mathrm{C}$ (DMFEtOH, 1:15). IR (ATR, cm ${ }^{-1}$ ): 3158 (-NH-), 3052 (Ar$\mathrm{CH}), 2976$ (Aliphatic $\mathrm{CH}), 1698(\mathrm{C}=\mathrm{O}), 1563(\mathrm{C}=\mathrm{N})$. ${ }^{1} \mathrm{H}$ NMR (400 MHz, DMSO-d 6 ) $\delta$ (ppm): 2.12 (s, 3H, $\left.\mathrm{CH}_{3}\right), 4.56\left(\mathrm{~s}, 2 \mathrm{H},-\mathrm{CH}_{2}\right)$, Arom-H $[7.59(\mathrm{~d}, J=7.6 \mathrm{~Hz}$, $2 \mathrm{H}), 7.36(\mathrm{t}, J=8.4,8.0 \mathrm{~Hz}, 1 \mathrm{H})], 13.26(\mathrm{~s}, 1 \mathrm{H}, \mathrm{NH}) .{ }^{13} \mathrm{C}$ NMR (400 MHz, DMSO-d 6 , $\delta$ ppm): $22.77\left(\mathrm{CH}_{3}\right), 31.75$ $\left(-\mathrm{CH}_{2}\right)$, Arom-C $[129.15(\mathrm{CH}), 130.56(\mathrm{CH}), 133.63$ (C), 135.48 (C)], Thiadiazole-C [159.99 (C), 160.26 (C)], 169.01 C $=$ O. Anal. Calcd. for $\mathrm{C}_{11} \mathrm{H}_{9} \mathrm{Cl}_{2} \mathrm{~N}_{3} \mathrm{OS}$ : C, 43.72; $\mathrm{H}, 3.00$; N, 13.91. Found: C, 43.76; H, 3.09; N, 13.86. MS $(\mathrm{ESI}-m / z): 302.01\left(\mathrm{M}^{+}, 85\right)$.

\section{Ethyl 5-(2,6-Dichlorobenzyl)-1,3,4-thiadiazol-2-ylcarbamate (6n)}

White solid, yield: 0.76 g (56\%), m.p. $217-218{ }^{\circ} \mathrm{C}$ (DMF$\mathrm{EtOH}, 1: 5)$. IR (ATR, $\left.\mathrm{cm}^{-1}\right): 3160(-\mathrm{NH}-), 3022$ (Ar$\mathrm{CH}), 2982$ (Aliphatic $\mathrm{CH}), 1720(\mathrm{C}=\mathrm{O}), 1569(\mathrm{C}=\mathrm{N})$. ${ }^{1} \mathrm{H}$ NMR (400 MHz, DMSO- $\left.\mathrm{d}_{6}\right) \delta(\mathrm{ppm}): 1.23(\mathrm{t}, 3 \mathrm{H}$, $\left.-\mathrm{CH}_{3}\right), 4.17\left(\mathrm{q}, 2 \mathrm{H},-\mathrm{OCH}_{2}-\right), 4.41\left(\mathrm{~s}, 2 \mathrm{H},-\mathrm{CH}_{2}\right)$, Arom-H [7.51 (d, 2H), $7.36(\mathrm{t}, 1 \mathrm{H})], 12.08$ (s, 1H, NH). ${ }^{13} \mathrm{C}$ NMR (400 MHz, DMSO-d 6 , $\delta$ ppm): $14.65\left(-\mathrm{CH}_{3}\right)$, $27.00\left(-\mathrm{CH}_{2}-\right), 62.60\left(-\mathrm{OCH}_{2}-\right)$, Arom-C [129.20 (CH), $130.37(\mathrm{CH}), 133.83(\mathrm{C}), 135.42(\mathrm{C})]$, Thiadiazole-C [160.63 (C), $161.48(\mathrm{C})$ ], $162.49 \mathrm{C}=\mathrm{O}$. Anal. Calcd. for $\mathrm{C}_{12} \mathrm{H}_{11} \mathrm{Cl}_{2} \mathrm{~N}_{3} \mathrm{O}_{2} \mathrm{~S}: \mathrm{C}, 43.39 ; \mathrm{H}, 3.34 ; \mathrm{N}, 12.65$. Found: $\mathrm{C}$, 43.33; H, 3.27; N, 12.56. MS (ESI-m/z): 331.14 (M-1, 93).

\section{N-(5-(2-Chloro-6-fluorobenzyl)-1,3,4-thiadiazol-2-yl)benza- mide (7a)}

White solid, yield:1.13 g (81\%), m.p. $258-259{ }^{\circ} \mathrm{C}$ (DMF$\mathrm{EtOH}, 1: 2)$. IR (ATR, $\left.\mathrm{cm}^{-1}\right): 3174(-\mathrm{NH}-), 3054$ (Ar$\mathrm{CH}), 2977$ (Aliphatic $\mathrm{CH}), 1670(\mathrm{C}=\mathrm{O}), 1580(\mathrm{C}=\mathrm{N}) .{ }^{1} \mathrm{H}$ NMR (400 MHz, DMSO-d $\left.{ }_{6}\right) \delta(\mathrm{ppm}): 4.49\left(\mathrm{~s}, 2 \mathrm{H},-\mathrm{CH}_{2}\right)$, Arom-H $[8.06(\mathrm{~d}, J=7.6 \mathrm{~Hz}, 2 \mathrm{H}), 7.62(\mathrm{t}, J=6.8 \mathrm{~Hz}, 1 \mathrm{H})$, 7.52 (t, J=7.2 Hz, 2H), 7.41 (bs, 2H), 7.30 (bd, 1H)], 12.99 (s, $1 \mathrm{H}, \mathrm{NH}) .{ }^{13} \mathrm{C}$ NMR (400 MHz, DMSO-d 6 , $\left.\delta \mathrm{ppm}\right)$ : $26.95\left(-\mathrm{CH}_{2}\right)$, Arom-C [115.27 (CH), $123.79(\mathrm{CH}), 126.14$ (C), $128.80(\mathrm{CH}), 129.07(\mathrm{CH}), 130.63(\mathrm{CH}), 131.92$ $(\mathrm{CH}), 133.41(\mathrm{C}), 134.82(\mathrm{C}), 161.13(\mathrm{C})]$, ThiadiazoleC [160.08 (C), 162.54 (C)], $165.55 \mathrm{C}=\mathrm{O}$. Anal. Calcd. for $\mathrm{C}_{16} \mathrm{H}_{11} \mathrm{ClFN}_{3} \mathrm{OS}$ : C, 55.25; H, 3.19; N, 12.08. Found: C, 55.31; H, 3.21; N, 12.11. MS: $m / z: 347.79\left(\mathrm{M}^{+}, 100\right)$, $348.81(\mathrm{M}+1,32)$.
N-(5-(2-Chloro-6-fluorobenzyl)-1,3,4-thiadiazol-2-yl)-4-nitrobenzamide (7b)

White solid, yield:1.19 g (76\%), m.p. 257-258 ${ }^{\circ} \mathrm{C}$ (DMFEtOH, 1:3). IR (ATR, $\left.\mathrm{cm}^{-1}\right)$ : 3116 (-NH-), 3039 (Ar$\mathrm{CH}), 2924$ (Aliphatic $\mathrm{CH}), 1679(\mathrm{C}=\mathrm{O}), 1604(\mathrm{C}=\mathrm{N}) .{ }^{1} \mathrm{H}$ NMR (400 MHz, DMSO-d $\left.{ }_{6}\right) \delta(\mathrm{ppm}): 4.50\left(\mathrm{~s}, 2 \mathrm{H},-\mathrm{CH}_{2}\right)$, Arom-H $[8.34(\mathrm{~d}, J=7.6 \mathrm{~Hz}, 2 \mathrm{H}), 8.26(\mathrm{~d}, J=8.0 \mathrm{~Hz}$, $2 \mathrm{H}), 7.38$ (d, 2H), 7.31 (bd, $1 \mathrm{H})], 13.39$ (s, $1 \mathrm{H}, \mathrm{NH}) \cdot{ }^{13} \mathrm{C}$ NMR (400 MHz, DMSO-d 6 , $\delta \mathrm{ppm})$ : $27.03\left(-\mathrm{CH}_{2}\right)$, Arom-C [115.28 (CH), $124.09(\mathrm{CH}), 126.12(\mathrm{CH}), 126.16$ (C), $130.41(\mathrm{CH}), 130.70(\mathrm{CH}), 130.89(\mathrm{C}), 134.82(\mathrm{C})$, 147.08 (C), $160.08(\mathrm{C})$ ], Thiadiazole-C [150.26 (C), 162.54 (C)], $167.10 \mathrm{C}=\mathrm{O}$. Anal. Calcd. for $\mathrm{C}_{16} \mathrm{H}_{10} \mathrm{ClFN}_{4} \mathrm{O}_{3} \mathrm{~S}$ : C, 48.92; H, 2.57; N, 14.26. Found: C, 48.88; H, 2.59; N, 14.22. MS: $m / z: 392.90\left(\mathrm{M}^{+}, 100\right), 394.72(\mathrm{M}+2,54)$.

\section{N-(5-(2-Chloro-6-fluorobenzyl)-1,3,4-thiadia-} zol-2-yl)-4-(methylthio) benzamide (7c)

White solid, yield:1.21 g (77\%), m.p. 275-276 ${ }^{\circ} \mathrm{C}$ (DMFEtOH, 1:2). IR (ATR, cm $\left.{ }^{-1}\right): 3158$ (-NH-), 3043 (Ar$\mathrm{CH}), 2949$ (Aliphatic $\mathrm{CH}), 1658(\mathrm{C}=\mathrm{O}), 1591(\mathrm{C}=\mathrm{N}) .{ }^{1} \mathrm{H}$ NMR (400 MHz, DMSO-d $\left.{ }_{6}\right) \delta$ (ppm): $2.51\left(\mathrm{~s}, 3 \mathrm{H},-\mathrm{CH}_{3}\right)$, $4.48\left(\mathrm{~s}, 2 \mathrm{H},-\mathrm{CH}_{2}\right)$, Arom-H $[8.01(\mathrm{~d}, J=6.8 \mathrm{~Hz}, 2 \mathrm{H}), 7.37$ (d, J=6.8 Hz, 2H), 7.35 (s, 2H), 7.29 (bs, 1H)], 12.90 (s, $1 \mathrm{H}, \mathrm{NH}) .{ }^{13} \mathrm{C}$ NMR (400 MHz, DMSO-d 6 , $\delta \mathrm{ppm}$ ): 14.39 $\left(\mathrm{CH}_{3}\right), 26.95\left(-\mathrm{CH}_{2}\right)$, Arom-C $[115.20(\mathrm{CH}), 123.89$ $(\mathrm{CH}), 125.32(\mathrm{C}), 126.12(\mathrm{CH}), 130.63(\mathrm{CH}), 130.73(\mathrm{CH})$, 134.88 (C), 139.69 (C), 145.70 (C), 161.14 (C)], Thiadiazole-C [160.09 (C), 162.54 (C)], $165.48 \mathrm{C}=\mathrm{O}$. Anal. Calcd. for $\mathrm{C}_{17} \mathrm{H}_{13} \mathrm{ClFN}_{3} \mathrm{OS}_{2}$ : C, 51.84; H, 3.33; N, 10.67 . Found: C, 51.79; H, 3.36; N, 10.62. MS (ESI-m/z): 411.38 $(\mathrm{M}+1,96), 413.34(\mathrm{M}+2,48)$.

\section{N-(5-(2-Chloro-6-fluorobenzyl)-1,3,4-thiadiazol-2-yl)-3,4-di-} chloro benzamide (7d)

White solid, yield:1.27 g (76\%), m.p. 214-215 ${ }^{\circ} \mathrm{C}$ (DMFEtOH, 1:11). IR (ATR, $\left.\mathrm{cm}^{-1}\right): 3092$ (-NH-), 3010 (Ar$\mathrm{CH}), 2928$ (Aliphatic CH), $1674(\mathrm{C}=\mathrm{O}), 1591(\mathrm{C}=\mathrm{N}) .{ }^{1} \mathrm{H}$ NMR (400 MHz, DMSO-d $\left.{ }_{6}\right) \delta$ (ppm): $4.82\left(\mathrm{~s}, 2 \mathrm{H},-\mathrm{CH}_{2}\right)$, Arom-H [8.30 (s, 1H), $7.99(\mathrm{~d}, J=8.4 \mathrm{~Hz}, 1 \mathrm{H}), 7.79$ (d, $J=8.4 \mathrm{~Hz}, 1 \mathrm{H}), 7.38(\mathrm{~d}, 2 \mathrm{H}), 7.29(\mathrm{t}, 1 \mathrm{H})], 13.15(\mathrm{~s}, 1 \mathrm{H}$, $\mathrm{NH}) .{ }^{13} \mathrm{C}$ NMR (400 MHz, DMSO-d 6 , $\delta$ ppm): $27.00(-$ $\left.\mathrm{CH}_{2}\right)$, Arom-C [115.26 (CH), $123.66(\mathrm{CH}), 126.11(\mathrm{C})$, $126.14(\mathrm{CH}), 129.03(\mathrm{CH}), 130.66(\mathrm{CH}), 130.76(\mathrm{CH})$, 131.39 (C), 131.99 (C), 134.82 (C), 136.17 (C), 160.08 (C)], Thiadiazole-C [159.85 (C), $162.53(\mathrm{C})], 164.12 \mathrm{C}=\mathrm{O}$. Anal. Calcd. for $\mathrm{C}_{16} \mathrm{H}_{9} \mathrm{Cl}_{3} \mathrm{FN}_{3} \mathrm{OS}$ : C, 46.12; H, 2.18; N, 10.08. Found: C, 46.17; H, 2.15; N, 10.12. MS (ESI-m/z): $417.60(\mathrm{M}+1,100)$. 
N-(5-(2-Chloro-6-fluorobenzyl)-1,3,4-thiadiazol-2-yl)-3,4-difluorobenz-amide (7e)

White solid, yield:1.21 g (79\%), m.p. $278-279{ }^{\circ} \mathrm{C}$ (DMFEtOH, 1:10). IR (ATR, $\left.\mathrm{cm}^{-1}\right): 3157$ (-NH-), $3063(\mathrm{Ar}-$ $\mathrm{CH}), 2979$ (Aliphatic $\mathrm{CH}), 1667(\mathrm{CvO}), 1608(\mathrm{C}=\mathrm{N})$. ${ }^{1} \mathrm{H}$ NMR (400 MHz, DMSO-d ${ }_{6}$ ) $\delta(\mathrm{ppm}): 4.49(\mathrm{~s}, 2 \mathrm{H},-$ $\mathrm{CH}_{2}$ ), Arom-H [8.14 (t, 1H), 7.95 (bs, $\left.1 \mathrm{H}\right), 7.62(\mathrm{q}, 1 \mathrm{H})$, 7.39 (bs, 2H), $7.29(\mathrm{t}, 1 \mathrm{H})], 13.09$ (s, 1H, NH). ${ }^{13} \mathrm{C}$ NMR (400 MHz, DMSO-d $\left.{ }_{6}, \delta \mathrm{ppm}\right): 26.99\left(-\mathrm{CH}_{2}\right)$, Arom-C [115.26 (CH), $118.33(\mathrm{CH}), 123.69(\mathrm{CH}), 126.11(\mathrm{CH})$, $126.71(\mathrm{CH}), 130.66(\mathrm{C}), 134.82(\mathrm{CH}), 148.45(\mathrm{C}), 150.78$ (C), 151.59 (C), 154.12 (C), 160.08 (C)], Thiadiazole-C [157.63 (C), $161.78(\mathrm{C})], 162.55 \mathrm{C}=\mathrm{O}$. Anal. Calcd. for $\mathrm{C}_{16} \mathrm{H}_{9} \mathrm{ClF}_{3} \mathrm{~N}_{3} \mathrm{OS}$ : C, 50.07; H, 2.36; N, 10.95. Found: C, 50.11; H, 2.33; N, 10.97. MS (ESI-m/z): $383.78\left(\mathrm{M}^{+}, 70\right)$, $385.15(\mathrm{M}+2,100)$.

\section{N-(5-(2-Chloro-6-fluorobenzyl)-1,3,4-thiadia-}

\section{zol-2-yl)-3,4-dimethoxy benzamide (7f)}

White solid, yield:1.11 g (68\%), m.p. $248-249{ }^{\circ} \mathrm{C}$ (DMF$\mathrm{EtOH}, 1: 4)$. IR (ATR, $\left.\mathrm{cm}^{-1}\right): 3178(-\mathrm{NH}-), 3088(\mathrm{Ar}-$ $\mathrm{CH}), 2940$ (Aliphatic $\mathrm{CH}), 1661(\mathrm{C}=\mathrm{N}), 1588(\mathrm{C}=\mathrm{N})$. ${ }^{1} \mathrm{H}$ NMR $\left(400 \mathrm{MHz}\right.$, DMSO-d $\left.{ }_{6}\right) \delta(\mathrm{ppm}): 3.82(\mathrm{~s}, 6 \mathrm{H}$, $\left.-\mathrm{OCH}_{3}\right), 4.47\left(\mathrm{~s}, 2 \mathrm{H},-\mathrm{CH}_{2}\right)$, Arom- $\mathrm{H}[7.73(\mathrm{~s}, 2 \mathrm{H})$, 7.39 (s, 2H), $7.30(\mathrm{~d}, 1 \mathrm{H}), 7.08(\mathrm{~d}, 1 \mathrm{H})], 12.82(\mathrm{~s}, 1 \mathrm{H}$, $\mathrm{NH}) .{ }^{13} \mathrm{C}$ NMR $\left(400 \mathrm{MHz}\right.$, DMSO-d $\left.\mathrm{d}_{6}, \delta \mathrm{ppm}\right): 26.89(-$ $\left.\mathrm{CH}_{2}\right), 56.10\left(-\mathrm{OCH}_{3}\right), 56.17\left(-\mathrm{OCH}_{3}\right)$, Arom-C [111.58 $(\mathrm{CH}), 115.03(\mathrm{CH}), 115.25(\mathrm{CH}), 122.86(\mathrm{CH}), 123.65$ $(\mathrm{CH}), 123.83(\mathrm{C}), 126.14(\mathrm{C}), 130.70(\mathrm{CH}), 134.82(\mathrm{C})$, 148.82 (C), 153.17 (C), 160.08 (C)], Thiadiazole-C [160.97 (C), 162.54 (C)], 164.70 C=O. Anal. Calcd. for $\mathrm{C}_{18} \mathrm{H}_{15} \mathrm{ClFN}_{3} \mathrm{O}_{3} \mathrm{~S}: \mathrm{C}, 53.01 ; \mathrm{H}, 3.71 ; \mathrm{N}, 10.30$. Found: C, 52.97; H, 3.74; N, 10.28. MS (ESI-m/z): $407.81\left(\mathrm{M}^{+}\right.$, 100), $409.91(\mathrm{M}+2,37)$.

\section{N-(5-(2-Chloro-6-fluorobenzyl)-1,3,4-thiadia-}

\section{zol-2-yl)-3,5-dimethoxy benzamide (7g)}

White solid, yield: $0.93 \mathrm{~g}$ (57\%), m.p. $252-254{ }^{\circ} \mathrm{C}$ (DMF$\mathrm{EtOH}, 1: 1)$. IR (ATR, $\left.\mathrm{cm}^{-1}\right): 3268(-\mathrm{NH}-), 3109(\mathrm{Ar}-$ $\mathrm{CH}), 2947$ (Aliphatic $\mathrm{CH}), 1624(\mathrm{C}=\mathrm{O}), 1580(\mathrm{C}=\mathrm{N})$. ${ }^{1} \mathrm{H}$ NMR (400 MHz, DMSO-d $\left.{ }_{6}\right) \delta(\mathrm{ppm}): 3.76(\mathrm{~s}, 6 \mathrm{H},-$ $\left.\mathrm{OCH}_{3}\right), 4.39\left(\mathrm{~s}, 2 \mathrm{H},-\mathrm{CH}_{2}\right)$, Arom- $\mathrm{H}[7.75(\mathrm{~d}, 1 \mathrm{H}), 7.34$ (t, 1H), 7.04 (s, 2H), $6.71(\mathrm{~s}, 2 \mathrm{H})], 13.03(\mathrm{bs}, 1 \mathrm{H}, \mathrm{NH})$. ${ }^{13} \mathrm{C}$ NMR (400 MHz, DMSO- $\left.\mathrm{d}_{6}, \delta \mathrm{ppm}\right): 26.93\left(-\mathrm{CH}_{2}\right)$, $56.10\left(-\mathrm{OCH}_{3}\right), 56.17\left(-\mathrm{OCH}_{3}\right)$, Arom- $\mathrm{C}[111.56(\mathrm{CH})$, $115.31(\mathrm{CH}), 122.86(\mathrm{CH}), 123.65(\mathrm{CH}), 126.14(\mathrm{C})$, $130.76(\mathrm{CH}), 134.87(\mathrm{C}), 148.82(\mathrm{C}), 160.08(\mathrm{C}), 160.97$ (C)], Thiadiazole-C [153.25 (C), 162.54 (C)], 164.70 $\mathrm{C}=\mathrm{O}$. Anal. Calcd. for $\mathrm{C}_{18} \mathrm{H}_{15} \mathrm{ClFN}_{3} \mathrm{O}_{3} \mathrm{~S}: \mathrm{C}, 53.01 ; \mathrm{H}$, 3.71; N, 10.30. Found: C, 53.05; H, 3.69; N, 10.29. MS $(\mathrm{ESI}-m / z): 409.09(\mathrm{M}+1,96)$.
N-(5-(2-Chloro-6-fluorobenzyl)-1,3,4-thiadiazol-2-yl)-3,5-difluoro benzamide (7h)

White solid, yield: 1.24 g (81\%), m.p. $261-262{ }^{\circ} \mathrm{C}$ (DMF-EtOH, 1:2). IR (ATR, $\mathrm{cm}^{-1}$ ): 3154 (-NH-), 3096 (Ar-CH), 2932 (Aliphatic CH), $1677(\mathrm{C}=\mathrm{O}), 1597$ $(\mathrm{C}=\mathrm{N}) .{ }^{1} \mathrm{H}$ NMR $\left(400 \mathrm{MHz}, \mathrm{DMSO}-\mathrm{d}_{6}\right) \delta(\mathrm{ppm}): 4.49$ $\left(\mathrm{s}, 2 \mathrm{H},-\mathrm{CH}_{2}\right)$, Arom-H [7.77 (s, 2H), $7.58(\mathrm{t}, 1 \mathrm{H}), 7.40$ (bs, 2H), $7.30(\mathrm{t}, 1 \mathrm{H})], 13.16(\mathrm{~s}, 1 \mathrm{H}, \mathrm{NH}) .{ }^{13} \mathrm{C}$ NMR (400 MHz, DMSO-d $\left.\mathrm{d}_{6}, \delta \mathrm{ppm}\right): 26.99\left(-\mathrm{CH}_{2}\right)$, Arom-C [108.64 $(\mathrm{CH}), 112.16(\mathrm{CH}), 112.44(\mathrm{CH}), 115.28(\mathrm{CH})$, $123.68(\mathrm{C}), 126.13(\mathrm{CH}), 130.69(\mathrm{C}), 134.82(\mathrm{C}), 160.08$ (C), $163.81(\mathrm{C})]$, Thiadiazole-C [161.35 (C), 162.54 (C)], 163.94 C=O. Anal. Calcd. for $\mathrm{C}_{16} \mathrm{H}_{9} \mathrm{ClF}_{3} \mathrm{~N}_{3} \mathrm{OS}$ : C, 50.07; H, 2.36; N, 10.95. Found: C, 50.05; H, 2.38; N, 10.99. MS $($ ESI- $m / z): 383.87\left(\mathrm{M}^{+}, 100\right), 385.83(\mathrm{M}+2,53)$.

N-(5-(2-Chloro-6-fluorobenzyl)-1,3,4-thiadiazol-2-yl)-3,5-dichloro benzamide (7i)

White solid, yield:1.25 g (75\%), m.p. 277-278 ${ }^{\circ} \mathrm{C}$ (DMF$\mathrm{EtOH}, 1: 2)$. IR (ATR, $\left.\mathrm{cm}^{-1}\right)$ : $3140(-\mathrm{NH}-), 3082(\mathrm{Ar}-$ $\mathrm{CH}), 2913$ (Aliphatic $\mathrm{CH}), 1677(\mathrm{C}=\mathrm{O}), 1569(\mathrm{C}=\mathrm{N}) .{ }^{1} \mathrm{H}$ NMR (400 MHz, DMSO-d 6 ) $\delta(\mathrm{ppm}): 4.62\left(\mathrm{~s}, 2 \mathrm{H},-\mathrm{CH}_{2}\right)$, Arom-H [8.06 (s, 2H), $7.89(\mathrm{~s}, 1 \mathrm{H}), 7.40(\mathrm{~m}, 2 \mathrm{H}), 7.29(\mathrm{~m}$, $1 \mathrm{H})], 13.17$ (s, $1 \mathrm{H}, \mathrm{NH}) .{ }^{13} \mathrm{C}$ NMR $(400 \mathrm{MHz}, \mathrm{DMSO}-$ $\left.\mathrm{d}_{6}, \delta \mathrm{ppm}\right): 27.00\left(-\mathrm{CH}_{2}\right)$, Arom-C [115.28 $(\mathrm{CH}), 123.64$ $(\mathrm{CH}), 126.12(\mathrm{C}), 127.60(\mathrm{CH}), 130.68(\mathrm{CH}), 130.78(\mathrm{CH})$, $132.51(\mathrm{C}), 134.81(\mathrm{C}), 134.87$ (C), $134.91(\mathrm{C})]$, Thiadiazole-C $[160.07(\mathrm{C}), 162.54(\mathrm{C})], 164.21 \mathrm{C}=\mathrm{O}$. Anal. Calcd. for $\mathrm{C}_{16} \mathrm{H}_{9} \mathrm{Cl}_{3} \mathrm{FN}_{3} \mathrm{OS}$ : C, 46.12; $\mathrm{H}, 2.18 ; \mathrm{N}, 10.08$. Found: $\mathrm{C}$, 46.09; H, 2.16; N, 10.11. MS (ESI-m/z): $417.10\left(\mathrm{M}^{+}, 90\right)$.

N-(5-(2-Chloro-6-fluorobenzyl)-1,3,4-thiadiazol-2-yl)-4-ethylbenzamide (7j)

White solid, yield: $1.11 \mathrm{~g}$ (74\%), m.p. $243-244{ }^{\circ} \mathrm{C}$ (DMF$\mathrm{EtOH}, 1: 1)$. IR (ATR, $\left.\mathrm{cm}^{-1}\right): 3182(-\mathrm{NH}-), 3056(\mathrm{Ar}-$ $\mathrm{CH}), 2966$ (Aliphatic $\mathrm{CH}), 1662(\mathrm{C}=\mathrm{O}), 1580(\mathrm{C}=\mathrm{N})$. ${ }^{1} \mathrm{H}$ NMR (400 MHz, DMSO-d $\left.{ }_{6}\right) \delta(\mathrm{ppm}): 1.20(\mathrm{t}, 3 \mathrm{H},-$ $\left.\mathrm{CH}_{3}\right), 2.66$ (q, $\left.2 \mathrm{H},-\mathrm{CH}_{2}-\right), 4.48\left(\mathrm{~s}, 2 \mathrm{H},-\mathrm{CH}_{2}\right)$, Arom- $\mathrm{H}$ [7.99 (d, J=8.0 Hz, 2H), 7.39 (m, 4H), $7.29(\mathrm{~m}, 1 \mathrm{H})], 12.89$ (s, $1 \mathrm{H}, \mathrm{NH}) .{ }^{13} \mathrm{C}$ NMR (400 MHz, DMSO-d,$\delta \mathrm{ppm}$ ): $15.60\left(-\mathrm{CH}_{3}\right), 26.92\left(-\mathrm{CH}_{2}-\right), 28.57\left(-\mathrm{CH}_{2} \mathrm{CH}_{3}\right)$, AromC [115.28 (CH), $123.63(\mathrm{CH}), 126.11(\mathrm{C}), 128.47(\mathrm{CH})$, $128.95(\mathrm{CH}), 129.34(\mathrm{CH}), 130.62(\mathrm{C}), 134.87(\mathrm{C}), 149.84$ (C), 160.09 (C)], Thiadiazole-C [161.07 (C), 162.55 (C)], $165.56 \mathrm{C}=\mathrm{O}$. Anal. Calcd. for $\mathrm{C}_{18} \mathrm{H}_{15} \mathrm{ClFN}_{3} \mathrm{OS}$ : C, 57.52; H, 4.02; N, 11.18. Found: C, 57.49; H, 4.05; N, 11.21. MS $(\mathrm{ESI}-m / z): 375.02(\mathrm{M}-1,91)$.

\section{N-(5-(2-Chloro-6-fluorobenzyl)-1,3,4-thiadia-} zol-2-yl)-4-(trifluoromethyl)-benzamide (7k)

White solid, yield: $1.18 \mathrm{~g}$ (71\%), m.p. $273-274{ }^{\circ} \mathrm{C}$ (DMF$\mathrm{EtOH}, 1: 1)$. IR (ATR, $\left.\mathrm{cm}^{-1}\right): 3144(-\mathrm{NH}-), 3052(\mathrm{Ar}-$ $\mathrm{CH}), 2933$ (Aliphatic $\mathrm{CH}), 1677(\mathrm{C}=\mathrm{O}), 1581(\mathrm{C}=\mathrm{N}) .{ }^{1} \mathrm{H}$ 
NMR (400 MHz, DMSO-d $\left.\mathrm{d}_{6}\right) \delta(\mathrm{ppm}): 4.49\left(\mathrm{~s}, 2 \mathrm{H},-\mathrm{CH}_{2}\right)$, Arom-H $[8.23(\mathrm{~d}, J=8.0 \mathrm{~Hz}, 2 \mathrm{H}), 7.90(\mathrm{~d}, J=8.4 \mathrm{~Hz}$, $2 \mathrm{H}), 7.39(\mathrm{~m}, 2 \mathrm{H}), 7.29(\mathrm{~m}, 1 \mathrm{H})], 13.27(\mathrm{~s}, 1 \mathrm{H}, \mathrm{NH})$. ${ }^{13} \mathrm{C}$ NMR (400 MHz, DMSO-d ${ }_{6}, \delta$ ppm): $26.97\left(-\mathrm{CH}_{2}\right)$, 122.84 $\left(\mathrm{CF}_{3}\right)$, Arom- $\mathrm{C}[115.27(\mathrm{CH}), 123.51(\mathrm{CH}), 125.98$ (C), $126.15(\mathrm{CH}), 129.77(\mathrm{CH}), 130.66(\mathrm{CH}), 132.66$ (C), 132.98 (C), 134.82 (C), 160.09 (C)], Thiadiazole-C [161.12 (C), $162.55(\mathrm{C})], 164.96 \mathrm{C}=\mathrm{O}$. Anal. Calcd. for $\mathrm{C}_{17} \mathrm{H}_{10} \mathrm{ClF}_{4} \mathrm{~N}_{3} \mathrm{OS}: \mathrm{C}, 49.11 ; \mathrm{H}, 2.42 ; \mathrm{N}, 10.11$. Found: $\mathrm{C}$, 49.07; H, 2.45; N, 10.13. MS (ESI-m/z): $415.90\left(\mathrm{M}^{+}, 93\right)$.

\section{N-(5-(2-Chloro-6-fluorobenzyl)-1,3,4-thiadiazol-2-yl)-4-cy- anobenzamide (7)}

White solid, yield: $1.25 \mathrm{~g}$ (84\%), m.p. $327-328{ }^{\circ} \mathrm{C}$ (DMFEtOH, 1:2). IR (ATR, $\mathrm{cm}^{-1}$ ): 3149 (-NH-), 3071 (Ar$\mathrm{CH}), 2926$ (Aliphatic $\mathrm{CH}), 2243(\mathrm{CN}), 1679(\mathrm{C}=\mathrm{O}), 1581$ $(\mathrm{C}=\mathrm{N}) .{ }^{1} \mathrm{H}$ NMR $\left(400 \mathrm{MHz}, \mathrm{DMSO}-\mathrm{d}_{6}\right) \delta(\mathrm{ppm}): 4.50$ $\left(\mathrm{s}, 2 \mathrm{H},-\mathrm{CH}_{2}\right)$, Arom-H $[8.19(\mathrm{~d}, J=8.4 \mathrm{~Hz}, 2 \mathrm{H}), 8.01(\mathrm{~d}$, $J=8.4 \mathrm{~Hz}, 2 \mathrm{H}), 7.40(\mathrm{~m}, 2 \mathrm{H}), 7.30(\mathrm{~m}, 1 \mathrm{H})], 13.25(\mathrm{~s}, 1 \mathrm{H}$, $\mathrm{NH}) .{ }^{13} \mathrm{C}$ NMR (400 MHz, DMSO-d $\left.\mathrm{d}_{6}, \delta \mathrm{ppm}\right): 27.02(-$ $\left.\mathrm{CH}_{2}\right), 118.56(\mathrm{CN})$, Arom-C [115.07 $(\mathrm{CH}), 115.30(\mathrm{C})$, $126.14(\mathrm{CH}), 126.17(\mathrm{CH}), 129.62(\mathrm{CH}), 130.69(\mathrm{CH})$, $130.79(\mathrm{CH}), 133.04(\mathrm{C}), 134.82(\mathrm{C}), 160.08(\mathrm{C})]$, Thiadiazole-C [154.73 (C), 162.54 (C)], 165.79 C=O. Anal. Calcd. for $\mathrm{C}_{17} \mathrm{H}_{10} \mathrm{ClFN}_{4} \mathrm{OS}$ : C, 54.77; H, 2.70; N, 15.03. Found: C, 54.78; H, 2.68; N, 15.07. MS (ESI-m/z): $372.97\left(\mathrm{M}^{+}, 92\right)$.

\section{N-(5-(2-Chloro-6-fluorobenzyl)-1,3,4-thiadiazol-2-yl)aceta- mide $(7 \mathrm{~m})$}

White solid, yield: $0.99 \mathrm{~g}(87 \%)$, m.p. $262-263{ }^{\circ} \mathrm{C}$ (DMFEtOH, 1:8). IR (ATR, $\mathrm{cm}^{-1}$ ): $3158(-\mathrm{NH}-), 3038$ (Ar$\mathrm{CH}), 2908$ (Aliphatic $\mathrm{CH}), 1699(\mathrm{C}=\mathrm{O}), 1558(\mathrm{C}=\mathrm{N}) .{ }^{1} \mathrm{H}$ NMR (400 MHz, DMSO-d $) \delta(\mathrm{ppm}): 2.13\left(\mathrm{~s}, 3 \mathrm{H},-\mathrm{CH}_{3}\right)$, $4.44\left(\mathrm{~s}, 2 \mathrm{H},-\mathrm{CH}_{2}\right)$, Arom- $\mathrm{H}[7.38(\mathrm{~m}, 2 \mathrm{H}), 7.28(\mathrm{~m}, 1 \mathrm{H})]$, $12.45(\mathrm{~s}, 1 \mathrm{H}, \mathrm{NH}) .{ }^{13} \mathrm{C}$ NMR $\left(400 \mathrm{MHz}, \mathrm{DMSO}-\mathrm{d}_{6}, \delta\right.$ ppm): $22.78\left(\mathrm{CH}_{3}\right), 26.88\left(-\mathrm{CH}_{2}\right)$, Arom-C [115.23 $(\mathrm{CH})$, $123.79(\mathrm{CH}), 126.11(\mathrm{C}), 130.69(\mathrm{CH}), 134.84(\mathrm{C}), 160.07$ (C)], Thiadiazole-C [159.08 (C), $162.51(\mathrm{C})], 169.03 \mathrm{C}=\mathrm{O}$. Anal. Calcd. for $\mathrm{C}_{11} \mathrm{H}_{9} \mathrm{ClFN}_{3} \mathrm{OS}: \mathrm{C}, 46.24 ; \mathrm{H}, 3.17 ; \mathrm{N}$, 14.71. Found: $C$, 46.26; $H, 3.14 ; \mathrm{N}, 14.69$. MS $(\mathrm{ESI}-m / z)$ : $286.11(\mathrm{M}+1,95)$.

\section{Ethyl 5-(2-Chloro-6-fluorobenzyl)-1,3,4-thiadiazol-2-ylcarba- mate (7n)}

White solid, yield: 0.80 g (63\%), m.p. $192-193{ }^{\circ} \mathrm{C}$ (DMF$\mathrm{EtOH}, 1: 5)$. IR (ATR, $\left.\mathrm{cm}^{-1}\right)$ : $3160(-\mathrm{NH}-), 3037$ (Ar$\mathrm{CH}), 2982$ (Aliphatic $\mathrm{CH}), 1720(\mathrm{C}=\mathrm{O}), 1569(\mathrm{C}=\mathrm{N}) .{ }^{1} \mathrm{H}$ NMR (400 MHz, DMSO-d $\left.\mathrm{d}_{6}\right) \delta(\mathrm{ppm}): 1.22\left(\mathrm{t}, 3 \mathrm{H},-\mathrm{CH}_{3}\right)$, $4.16\left(\mathrm{q}, 2 \mathrm{H},-\mathrm{OCH}_{2}-\right), 4.41\left(\mathrm{~s}, 2 \mathrm{H},-\mathrm{CH}_{2}\right)$, Arom- $\mathrm{H}[7.36$ $(\mathrm{m}, 2 \mathrm{H}), 7.25(\mathrm{~m}, 1 \mathrm{H})], 12.09(\mathrm{~s}, 1 \mathrm{H}, \mathrm{NH}) .{ }^{13} \mathrm{C}$ NMR (400 MHz, DMSO-d ${ }_{6}, \delta$ ppm): $14.65\left(-\mathrm{CH}_{3}\right), 26.96(-$ $\left.\mathrm{CH}_{2}-\right), 62.61\left(-\mathrm{OCH}_{2}-\right)$, Arom-C [115.18 $(\mathrm{CH}), 123.53$
(CH), $126.06(\mathrm{C}), 130.55(\mathrm{CH}), 134.77(\mathrm{C}), 160.03(\mathrm{C})]$, Thiadiazole-C [154.34 (C), 161.47 (C)], 162.49 CvO. Anal. Calcd. for $\mathrm{C}_{12} \mathrm{H}_{11} \mathrm{ClFN}_{3} \mathrm{O}_{2} \mathrm{~S}: \mathrm{C}, 45.65 ; \mathrm{H}, 3.51 ; \mathrm{N}, 13.31$. Found: C, 45.56; H, 3.48; N, 13.20. MS (ESI-m/z): 315.16 $\left(\mathrm{M}^{+}, 96\right)$.

\section{Crystallographic analysis}

The X-ray fraction data of the compound $7 \mathbf{n}$ examined in this study was collected using the $\mathrm{MoK}_{\alpha}$ ray at 293(2) $\mathrm{K}$ degree using a 'Bruker APEX-II CCD diffractometer. The structures of the crystals were solved using direct methods in ShelXT [43] software. During the process, in order to determine the positions of the atoms, except for hydrogen, the refinement procedure was conducted using the ShelXL [44] software [45] that used the fullmatrix least-squares method. After the structure solution and refinement procedures were finished, olex2 and MERCURY software were used in molecular drawings and calculations.

\section{Biological activity studies \\ Fungi culture}

Monilia fructigena, Fusarium oxysporum f. sp. lycopersici and Alternaria solani plant pathogens were used for the tests. The pathogens were grown on a PDA (potato dextrose agar) medium at $22 \pm 2{ }^{\circ} \mathrm{C}$ for about 7 days.

In vitro antifungal activity Antifungal activity studies were determined using disk diffusion method [46]. The compounds were dissolved in dimethyl sulphoxide (DMSO). In the laminar flow cabin, Whatman no. 1 sterile filter paper discs $(6 \mathrm{~mm})$ were impregnated with $50 \mu \mathrm{l}$ of the compounds (corresponding to 500 and $1000 \mu \mathrm{g} / \mathrm{ml}$ of compounds) and allowed to dry at room temperature (for $4 \mathrm{~h}$ ) [47]. Then the compound impregnated paper discs were placed in a PDA medium in $90 \mathrm{~mm}$ sterile petri plates. Mycelium discs (5 mm diameter) of 7-day-old culture of test fungi were inoculated to the centre of the Petri plate. All fungi were incubated at $22 \pm 2{ }^{\circ} \mathrm{C}$. There is a $25 \mathrm{~mm}$ distance between the mycelium discs and paper discs. The obtained inhibition zones were recorded. As negative control, only DMSO was impregnated to discs. In the positive control, $80 \%$ thiram $(3000 \mu \mathrm{g} / \mathrm{ml})$ was used against the test fungi at the recommended dose. All antifungal activity values were determined by measuring inhibition zone distance between pathogen and paper disc [24].

Percent inhibition was calculated according to the following formula:

$\%$ Inhibition $=$ Inhibition zone in treatment $/$ Control $^{*} \times 100$

*Control: Inhibition zone of positive control. 
Lethal doses $\left(L D_{50}\right)$, minimum fungicidal concentration (MFC) and minimum inhibitory concentration (MIC)

Minimum inhibitory concentration (MIC) and Minimum fungicidal concentration (MFC) of the compounds were tested by the twofold serial dilution method. The test compound was dissolved in DMSO to obtain $1000 \mu \mathrm{g} /$ $\mathrm{ml}$ stock solutions. For the MIC and MFC assay, each compound was prepared in the concentrations of 1000 , $500,250,125,62.5$ and $31.25 \mu \mathrm{g} / \mathrm{ml}$. Fifty microliter of concentrations of the compound was transferred on to paper disc. Then the same methods as described in the in vitro antifungal activity studies were applied. The MIC was defined as the lowest test concentration that allowed no detectable mycelium growth. The MFC was defined as the lowest test concentration that allows no mycelium growth of the organism on agar [48]. In addition, $\mathrm{LD}_{50}$ values were calculated. Six different doses used in the calculation of the MIC were calculated using the results of the inhibition zones. Lethal doses (LD) estimates for $\mathrm{LD}_{50}$ were determined with Polo Plus (LeOra software).

\section{Computational methods}

JSME [49] molecular editor was used to generate the structures of the ligands and Open Babel v2.4.1 [50] was used for conversion of file formats and optimization of chemical structures.

2D Similarity search was conducted by Tanimoto similarity equation to extract compounds similar to our structures using a similarity threshold of $90 \%$ against $\mathrm{NCBI}^{\prime} \mathrm{s}$ PubChem database consisting of $96,470,035$ compounds [51-53].

The amino acid sequences were retrieved from the Universal Protein Resource (UniProt). NCBI BLAST server was used to find similar protein sequences that corresponds to our target organisms [31-33].

Homology modelling studies were performed through the Automated Comparative Protein Modelling Server (SWISS-MODEL) [34]. Structural validation of the model was done via RAMPAGE and ERRAT servers [35, 36].

Molecular dynamics simulation study was performed using GROMACS v5.1.4 [54-56]. The protonation states of residues were assigned at $\mathrm{pH} 7$ in the $\mathrm{PDB}$ 2PQR web server using PROPKA [57]. All the systems were solvated using SPC water model in a rectangular box. CHARMM36 force field was used to generate protein topology, whereas CHARMM General Force Field (CGenFF) $[58,59]$ was used in ligand parametrization. $\mathrm{Na}^{+}$or $\mathrm{Cl}^{-}$ions were used to neutralize the system. In order to remove the steric clashes in the system, steepest energy minimization was performed [60]. Long range electrostatic interactions were calculated by PME method [61]. The time step was kept at 2 fs during the simulation. Then the equilibration simulation of $1 \mathrm{~ns}$ was carried out under NVT and NPT conditions. Finally, a molecular dynamic simulation of $50 \mathrm{~ns}$ for each system was performed. All the graphs were generated using Xmgrace. LeDock was used as a molecular docking tool. LePro was used for the preparation of the receptor structures. All the heteroatoms were deleted from the structures and the hydrogens were added by LePro $[62,63]$.

Schrodinger's QikProp [64] module was used to calculate some molecular descriptors such as molecular weight, total solvent accessible surface area (SASA), logarithm of octanol-water partition coefficient (QPlogPo/w), brain/blood partition coefficient (QPlogBB), apparent MDCK cell permeability (QPPMDCK), percent human oral absorption, polar surface area (PSA) and violations to the Lipinski's rule of five [41].

\section{Additional file}

Additional file 1. Experimental details and NMR spectra. Tables S1-S3. $\mathbf{X}$-ray data of compound $\mathbf{7 n}$. Figure $\mathbf{S 1}$. The crystal structure of compound $\mathbf{7 n}$. Figure S2. Packaging of the compound $7 \mathbf{n}$ over b-axis. Figure S3. The Radius of gyration (Rg) during 50 ns of MD simulation of STE/ STE20/YSK protein kinase homology model. Figures S4-S63. ${ }^{1} \mathrm{H}$ and ${ }^{13} \mathrm{C}$ NMR spectra of all the compounds.

\section{Authors' contributions}

Authors ME, AMA, HT, AHB and $\mathrm{AO}$ have designed, synthesized and carried out the antifungal activities of 2-amino-1,3,4-thiadiazole and their acyl derivatives. Authors SSÇ and AE have carried out the molecular modelling part including similarity search, homology modelling, molecular dynamics and molecular docking. All authors read and approved the final manuscript.

\section{Author details}

${ }^{1}$ Department of Chemistry, Faculty of Science, Karabuk University, 78050 Karabuk, Turkey. ${ }^{2}$ Department of Medical Biotechnology, Institute of Health Sciences, Acıbadem Mehmet Ali Aydınlar University, 34752 İstanbul, Turkey. ${ }^{3}$ Department of Plant Protection, Faculty of Agriculture, Gaziosmanpasa University, 60250 Tokat, Turkey. ${ }^{4}$ Department of Pharmaceutical Chemistry, Faculty of Pharmacy, Biruni University, 34010 Istanbul, Turkey.

\section{Acknowledgements}

The financial support under the contract (KBÜ-BAP-17-YL-265) from the Karabük University is gratefully acknowledged.

\section{Competing interests}

The authors declare that they have no competing interests.

\section{Publisher's Note}

Springer Nature remains neutral with regard to jurisdictional claims in published maps and institutional affiliations.

Received: 11 September 2018 Accepted: 3 November 2018 Published online: 23 November 2018

References

1. Dani RK, Bharty MK, Kushawaha SK et al (2013) Syntheses, spectral, X-ray and DFT studies of 5-benzyl-N-phenyl-1,3,4-thiadiazol-2-amine, 2-(5-phenyl-1,3,4-thiadiazol-2-yl) pyridine and 2-(5-methyl-1,3,4-thiadiazole-2-ylthio)-5-methyl-1,3,4-thiadiazole obtained by Mn(II) catalyzed 
reactions. J Mol Struct 1054-1055:251-261. https://doi.org/10.1016/j. molstruc.2013.09.051

2. Dong H-S, Quan B, Zhu D-W, Li W-D (2002) The crystal structure of 3-[5-methyl-1-(4-methylphenyl)-1,2,3-triazol-4-yl]-s-triazolo[3,4-b]-1,3,4thiadiazole. J Mol Struct 616:1-5. https://doi.org/10.1016/S0022 $-2860(01) 00935-8$

3. Han J, Chang X-Y, Wang Y-M, Pang M-L, Meng J-B (2009) Synthesis, crystal structures, mesomorphic and photo-luminescent properties of 1,3,4-thia(oxa)diazole-based compounds with a terminal methoxy or methylthio group. J Mol Struct 937:122-130. https://doi.org/10.1016/j. molstruc.2009.08.025

4. Egorov DM, Piterskaya YL, Dogadina AV, Svintsitskaya NI (2015) Reactions of 5-substituted 1,3,4-thiadiazole-2-thiones with chloroacetylenephosphonates. Tetrahedron Lett 56(12):1552-1554. https://doi.org/10.1016/j. tetlet.2015.02.027

5. Foroughifar N, Mobinikhaledi A, Ebrahimi S, Moghanian H, Fard MAB, Kalhor M (2009) Synthesis of a new class of azathia crown macrocycles containing two 1,2,4-triazole or two 1,3,4-thiadiazole rings as subunits. Tetrahedron Lett 50(7):836-839. https://doi.org/10.1016/j.tetle t.2008.12.014

6. Polkam N, Rayam P, Anireddy JS et al (2015) Synthesis, in vitro anticancer and antimycobacterial evaluation of new 5-(2,5-dimethoxyphenyl)-1,3,4thiadiazole-2-amino derivatives. Bioorg Med Chem Lett 25(7):1398-1402. https://doi.org/10.1016/j.bmcl.2015.02.052

7. Yoosefian M, Chermahini ZJ, Raissi H, Mola A, Sadeghi M (2015) A theoretical study on the structure of 2-amino-1,3,4-thiadiazole and its 5 -substituted derivatives in the gas phase, water, THF and DMSO solutions. J Mol Liq 203:137-142. https://doi.org/10.1016/j.molliq.2015.01.002

8. Farghaly TA, Abdallah MA, Masaret GS, Muhammad ZA (2015) New and efficient approach for synthesis of novel bioactive $[1,3,4]$ thiadiazoles incorporated with 1,3-thiazole moiety. Eur J Med Chem 97:320-333. https ://doi.org/10.1016/j.ejmech.2015.05.009

9. Chandrakantha B, Isloor AM, Shetty P, Fun HK, Hegde G (2014) Synthesis and biological evaluation of novel substituted 1,3,4-thiadiazole and 2,6-di aryl substituted imidazo $[2,1-b][1,3,4]$ thiadiazole derivatives. Eur J Med Chem 71:316-323. https://doi.org/10.1016/j.ejmech.2013.10.056

10. Camoutsis C, Geronikaki A, Ciric A, Soković M, Zoumpoulakis P, Zervou M (2010) Sulfonamide-1,2,4-thiadiazole derivatives as antifungal and antibacterial agents: synthesis, biological evaluation, lipophilicity, and conformational studies. Chem Pharm Bull 58(2):160-167. https://doi. org/10.1248/cpb.58.160

11. Hu Y, Li C-Y, Wang X-M, Yang Y-H, Zhu H-L (2014) 1,3,4-Thiadiazole: synthesis, reactions, and applications in medicinal, agricultural, and materials chemistry. Chem Rev 114(10):5572-5610. https://doi.org/10.1021/cr400 $131 \mathrm{u}$

12. Rodríguez-Calero GG, Conte S, Lowe MA et al (2015) Synthesis and characterization of poly-3,4-ethylenedioxythiophene/2,5-dimercapto-1,3,4thiadiazole (PEDOT-DMcT) hybrids. Electrochim Acta 167:55-60. https:// doi.org/10.1016/j.electacta.2015.02.159

13. Chandra S, Gautam S, Kumar A, Madan M (2015) Coordination mode of pentadentate ligand derivative of 5-amino-1,3,4-thiadiazole-2-thiol with nickel(II) and copper(II) metal ions: synthesis, spectroscopic characterization, molecular modeling and fungicidal study. Spectrochim Acta Part A Mol Biomol Spectrosc 136:672-681. https://doi.org/10.1016/j. saa.2014.09.081

14. Luo Y, Zhang S, Liu Z-J et al (2013) Synthesis and antimicrobical evaluation of a novel class of 1,3,4-thiadiazole: derivatives bearing 1,2,4-triazolo[1,5-a]pyrimidine moiety. Eur J Med Chem 64:54-61. https:// doi.org/10.1016/j.ejmech.2013.04.014

15. Kadi AA, Al-Abdullah ES, Shehata IA, Habib EE, Ibrahim TM, El-Emam AA (2010) Synthesis, antimicrobial and anti-inflammatory activities of novel 5-(1-adamantyl)-1,3,4-thiadiazole derivatives. Eur J Med Chem 45(11):5006-5011. https://doi.org/10.1016/j.ejmech.2010.08.007

16. Luszczki JJ, Karpińska M, Matysiak J, Niewiadomy A (2015) Characterization and preliminary anticonvulsant assessment of some 1,3,4-thiadiazole derivatives. Pharmacol Rep 67(3):588-592. https://doi.org/10.1016/j.phare p.2014.12.008

17. Barbuceanu S-F, Saramet G, Almajan GL, Draghici C, Barbuceanu F, Bancescu G (2012) New heterocyclic compounds from 1,2,4-triazole and 1,3,4-thiadiazole class bearing diphenylsulfone moieties. Synthesis, characterization and antimicrobial activity evaluation. Eur J Med Chem 49:417-423. https://doi.org/10.1016/j.ejmech.2012.01.031

18. Kumar S, Gopalakrishnan V, Hegde M et al (2014) Synthesis and antiproliferative activity of imidazo[2,1-b][1,3,4]thiadiazole derivatives. Bioorg Med Chem Lett 24(19):4682-4688. https://doi.org/10.1016/j.bmcl.2014.08.032

19. Revelant G, Gadais C, Mathieu V, Kirsch G, Hesse S (2014) Synthesis and antiproliferative studies of 5-aryl-2-(3-thienylamino)-1,3,4-thiadiazoles. Bioorg Med Chem Lett 24(12):2724-2727. https://doi.org/10.1016/j. bmcl.2014.04.043

20. Cressier D, Prouillac C, Hernandez P et al (2009) Synthesis, antioxidant properties and radioprotective effects of new benzothiazoles and thiadiazoles. Bioorg Med Chem 17(14):5275-5284. https://doi.org/10.1016/j. bmc.2009.05.039

21. Yamagami C, Takao N, Fujita T (1995) Analysis and prediction of 1-octanol/water partition coefficients of substituted diazines with substituent and structural parameters. QSAR and drug design-new development and applications. Elsevier, Amsterdam, pp 153-183. https:// doi.org/10.1016/s0165-7208(06)80049-8

22. Devillers J (1998) Comparative Qsar. CRC Press, New York

23. Debnath AK (2001) Quantitative structure-activity relationship (QSAR): a versatile tool in drug design. In: Ghose A, Viswanadhan V (eds) Combinatorial library design and evaluation principles, software, tools, and applications in drug discovery. CRC Press, New York, pp 73-129

24. Er M, Ergüven B, Tahtaci H, Onaran A, Karakurt T, Ece A (2017) Synthesis, characterization, preliminary SAR and molecular docking study of some novel substituted imidazo[2,1-b][1,3,4]thiadiazole derivatives as antifungal agents. Med Chem Res 26(3):615-630. https://doi.org/10.1007/s0004 4-017-1782-4

25. Er M, Isildak G, Tahtaci H, Karakurt T (2016) Novel 2-amino-1,3,4-thiadiazoles and their acyl derivatives: synthesis, structural characterization, molecular docking studies and comparison of experimental and computational results. J Mol Struct 1110:102-113. https://doi.org/10.1016/j. molstruc.2016.01.045

26. Janeczko M, Masłyk M, Kubiński K, Golczyk H (2017) Emodin, a natural inhibitor of protein kinase CK2, suppresses growth, hyphal development, and biofilm formation of Candida albicans. Yeast 34(6):253-265. https:// doi.org/10.1002/yea.3230

27. Santos Júnior HM, Campos VAC, Alves DS et al (2014) Antifungal activity of flavonoids from Heteropterys byrsonimifolia and a commercial source against Aspergillus ochraceus: in silico interactions of these compounds with a protein kinase. Crop Prot 62:107-114. https://doi.org/10.1016/j. cropro.2014.04.012

28. Kilic-Kurt Z, Bakar F, Ölgen S (2015) Synthesis, biological, and computational evaluation of novel 1,3,5-substituted indolin-2-one derivatives as inhibitors of src tyrosine kinase. Arch Pharm (Weinheim) 348(10):715-729. https://doi.org/10.1002/ardp.201500109

29. Hu L, Cao T, Lv Y et al (2016) Design, synthesis, and biological activity of 4-(imidazo[1,2-b]pyridazin-3-yl)-1 H-pyrazol-1-yl-phenylbenzamide derivatives as BCR-ABL kinase inhibitors. Bioorg Med Chem Lett 26(23):58305835. https://doi.org/10.1016/j.bmcl.2016.10.007

30. Grädler U, Bomke J, Musil D et al (2013) Fragment-based discovery of focal adhesion kinase inhibitors. Bioorg Med Chem Lett 23(19):54015409. https://doi.org/10.1016/j.bmcl.2013.07.050

31. Johnson M, Zaretskaya I, Raytselis Y, Merezhuk Y, McGinnis S, Madden TL (2008) NCBI BLAST: a better web interface. Nucleic Acids Res. https://doi. org/10.1093/nar/gkn201

32. Altschul SF, Gish W, Miller W, Myers EW, Lipman DJ (1990) Basic local alignment search tool. J Mol Biol 215(3):403-410. https://doi.org/10.1016/ S0022-2836(05)80360-2

33. UniProt Consortium (2018) T. UniProt: the universal protein knowledgebase. Nucleic Acids Res 46(5):2699. https://doi.org/10.1093/nar/gky092

34. Guex N, Peitsch MC (2003) SWISS-MODEL: an automated protein SWISSMODEL: an automated protein. Nucleic Acids Res 31:3381-3385. https:// doi.org/10.1093/nar/gkg520

35. Lovell SC, Davis IW, Adrendall WB et al (2003) Structure validation by C alpha geometry: phi, psi and C beta deviation. Proteins Structure Funct Genet 50:437-450. https://doi.org/10.1002/prot.10286

36. Colovos C, Yeates TO (1993) Verification of protein structures: patterns of nonbonded atomic interactions. Protein Sci 2(9):1511-1519. https://doi. org/10.1002/pro.5560020916 
37. Mascarenhas NM, Ghoshal N (2008) An efficient tool for identifying inhibitors based on 3D-QSAR and docking using feature-shape pharmacophore of biologically active conformation - a case study with CDK2/CyclinA. Eur J Med Chem 43(12):2807-2818

38. Ece A, Sevin F (2013) The discovery of potential cyclin A/CDK2 inhibitors: a combination of 3D QSAR pharmacophore modeling, virtual screening, and molecular docking studies. Med Chem Res 16;22(12):5832-5843

39. Tahtaci H, Karacık H, Ece A, Er M, Şeker MG (2018) Design, synthesis, SAR and molecular modeling studies of novel imidazo[2,1-b][1,3,4] thiadiazole derivatives as highly potent antimicrobial agents. Mol Inform 37(3):1700083

40. Veber DF, Johnson SR, Cheng H et al (2002) Molecular properties that influence the oral bioavailability of drug candidates. J Med Chem 45:2615-2623. https://doi.org/10.1021/jm020017n

41. Lipinski CA, Lombardo F, Dominy BW, Feeney PJ (2012) Experimental and computational approaches to estimate solubility and permeability in drug discovery and development settings. Adv Drug Deliv Rev 64:4-17

42. Schrödinger. Maestro|Schrödinger. Schrödinger Release 2018-3. 2018

43. Sheldrick GM (2015) SHELXT-integrated space-group and crystal-structure determination. Acta Crystallogr Sect A Found Adv 71(1):3-8. https:// doi.org/10.1107/S2053273314026370

44. Sheldrick GM (2015) Crystal structure refinement with SHELXL. Acta Crystallogr Sect C Struct Chem 71(1):3-8. https://doi.org/10.1107/S205322961 4024218

45. Dolomanov OV, Bourhis LJ, Gildea RJ, Howard JAK, Puschmann H (2009) OLEX2: a complete structure solution, refinement and analysis program. J Appl Crystallogr 42(2):339-341. https://doi.org/10.1107/S002188980 8042726

46. Barry LA (1985) Susceptibility tests : diffusion test procedure. Man Clin Microbiol 978-987. http://ci.nii.ac.jp/naid/10025872873/en/. Accessed 3 Sept 2018

47. Chandrasekaran M, Venkatesalu V (2004) Antibacterial and antifungal activity of Syzygium jambolanum seeds. J Ethnopharmacol 91(1):105-108. https://doi.org/10.1016/j.jep.2003.12.012

48. Babu KS, Li XC, Jacob MR et al (2006) Synthesis, antifungal activity, and structure-activity relationships of coruscanone A analogues. J Med Chem 49(26):7877-7886. https://doi.org/10.1021/jm061123i

49. Bienfait B, Ertl PJSME (2013) A free molecule editor in JavaScript. J Cheminform. https://doi.org/10.1186/1758-2946-5-24

50. O'Boyle NM, Banck M, James CA, Morley C, Vandermeersch T, Hutchison GR (2011) Open babel: an open chemical toolbox. J Cheminform. https:// doi.org/10.1186/1758-2946-3-33

51. Willett $P$ (2006) Similarity-based virtual screening using $2 D$ fingerprints. Drug Discov Today 11(23-24):1046-1053. https://doi.org/10.1016/j.drudi s.2006.10.005
52. Bolton EE, Wang $Y$, Thiessen PA, Bryant SH (2008) PubChem: integrated platform of small molecules and biological activities. Annu Rep Comput Chem 4:217-241. https://doi.org/10.1016/s1574-1400(08)00012-1

53. Kim S, Thiessen PA, Bolton EE et al (2016) PubChem substance and compound databases. Nucleic Acids Res 44(D1):D1202-D1213. https://doi. org/10.1093/nar/gkv951

54. Lindahl E, Hess B, van der Spoel D (2001) GROMACS 3.0: a package for molecular simulation and trajectory analysis. J Mol Model 7(8):306-317. https://doi.org/10.1007/s008940100045

55. Van Der Spoel D, Lindahl E, Hess B, Groenhof G, Mark AE, Berendsen HJC (2005) GROMACS: fast, flexible, and free. J Comput Chem 26(16):17011718. https://doi.org/10.1002/jcc.20291

56. Berendsen HJC, van der Spoel D, van Drunen R (1995) GROMACS: a message-passing parallel molecular dynamics implementation. Comput Phys Commun 91(1-3):43-56. https://doi.org/10.1016/0010-4655(95)00042-E

57. Dolinsky TJ, Nielsen JE, McCammon JA, Baker NA (2004) PDB2PQR: an automated pipeline for the setup of Poisson-Boltzmann electrostatics calculations. Nucleic Acids Res. https://doi.org/10.1093/nar/gkh381

58. Vanommeslaeghe K, Raman EP, MacKerell AD (2012) Automation of the CHARMM General Force Field (CGenFF) II: assignment of bonded parameters and partial atomic charges. J Chem Inf Model 52(12):3155-3168. https://doi.org/10.1021/ci3003649

59. Huang J, Mackerell AD (2013) CHARMM36 all-atom additive protein force field: validation based on comparison to NMR data. J Comput Chem 34(25):2135-2145. https://doi.org/10.1002/jcc.23354

60. Brereton RG (2010) Steepest ascent, steepest descent, and gradient methods. Comprehen Chemometr 1:577-590. https://doi.org/10.1016/ B978-044452701-1.00037-5

61. Essmann U, Perera L, Berkowitz ML, Darden T, Lee H, Pedersen LG (1995) A smooth particle mesh Ewald method. J Chem Phys 103(19):8577-8593. https://doi.org/10.1063/1.470117

62. Zhao H, Caflisch A (2013) Discovery of ZAP70 inhibitors by high-throughput docking into a conformation of its kinase domain generated by molecular dynamics. Bioorganic Med Chem Lett 23(20):5721-5726. https ://doi.org/10.1016/j.bmcl.2013.08.009

63. Wang Z, Sun H, Yao X et al (2016) Comprehensive evaluation of ten docking programs on a diverse set of protein-ligand complexes: the prediction accuracy of sampling power and scoring power. Phys Chem Chem Phys 18(18):12964-12975. https://doi.org/10.1039/C6CP01555G

64. Schrödinger Release 2018-3 (2018) QikProp, Schrödinger, LLC, New York
Ready to submit your research? Choose BMC and benefit from:

- fast, convenient online submission

- thorough peer review by experienced researchers in your field

- rapid publication on acceptance

- support for research data, including large and complex data types

- gold Open Access which fosters wider collaboration and increased citations

- maximum visibility for your research: over $100 \mathrm{M}$ website views per year

At BMC, research is always in progress.

Learn more biomedcentral.com/submissions 